\title{
Digital Surfaces and Thicknesses of Selected Hydrogeologic Units Within the Ozark Plateaus Aquifer System, Northwestern Arkansas
}

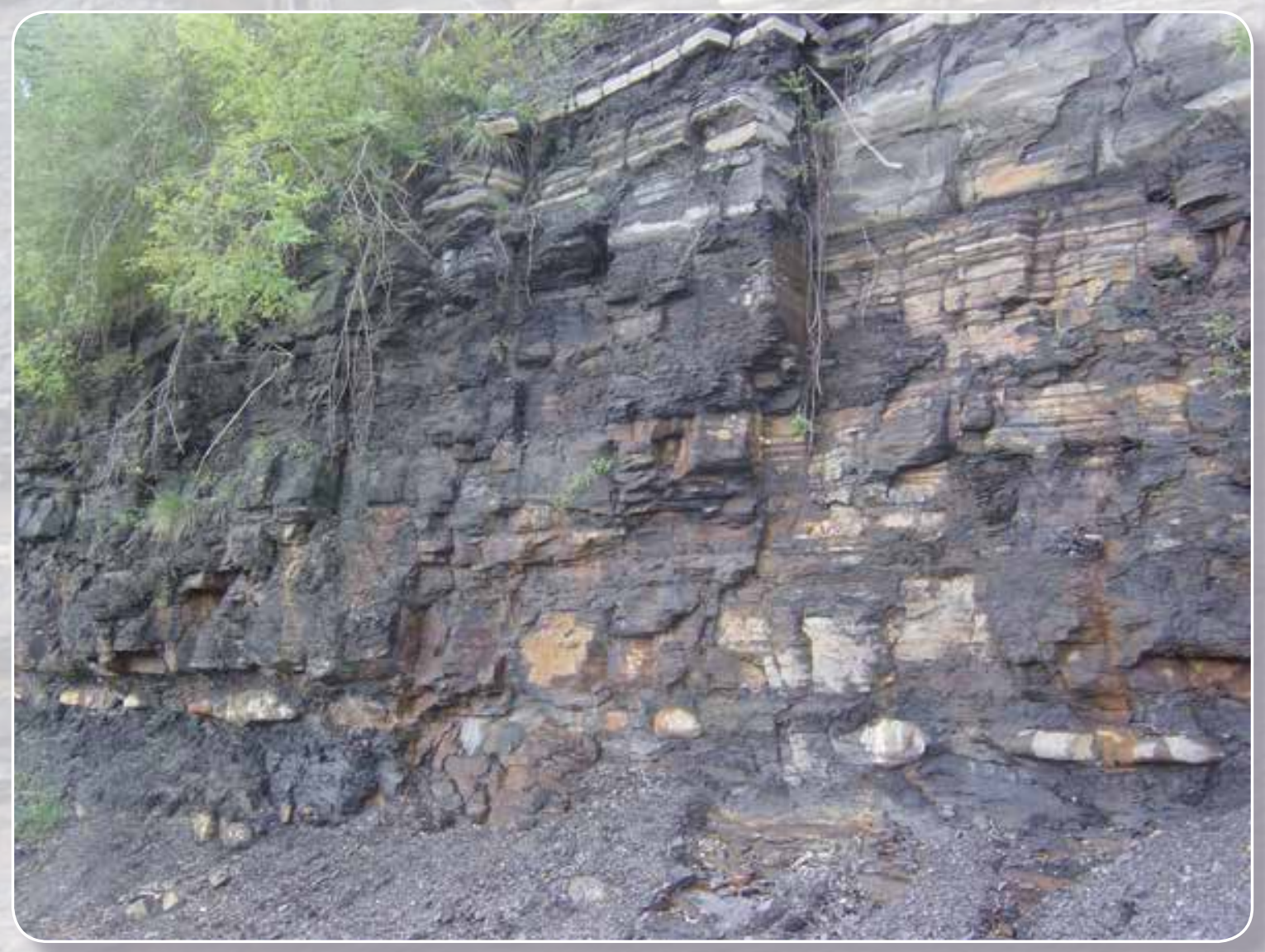

Scientific Investigations Report 2013-5208 
Cover: Outcrop of Chattanooga Shale along Highway 71 in Benton County, Arkansas. Photograph by John B. Czarnecki, U.S. Geological Survey. 


\section{Digital Surfaces and Thicknesses of Selected Hydrogeologic Units Within the Ozark Plateaus Aquifer System, Northwestern Arkansas}

By John B. Czarnecki, Susan E. Bolyard, Rheannon M. Hart, and Jimmy M. Clark

Scientific Investigations Report 2013-5208 


\section{U.S. Department of the Interior \\ SALLY JEWELL, Secretary}

\section{U.S. Geological Survey \\ Suzette M. Kimball, Acting Director}

\section{U.S. Geological Survey, Reston, Virginia: 2014}

For more information on the USGS — the Federal source for science about the Earth, its natural and living resources, natural hazards, and the environment, visit http://www.usgs.gov or call 1-888-ASK-USGS.

For an overview of USGS information products, including maps, imagery, and publications, visit http://www.usgs.gov/pubprod

To order this and other USGS information products, visit http://store.usgs.gov

Any use of trade, firm, or product names is for descriptive purposes only and does not imply endorsement by the U.S. Government.

Although this information product, for the most part, is in the public domain, it also may contain copyrighted materials as noted in the text. Permission to reproduce copyrighted items must be secured from the copyright owner.

Suggested citation:

Czarnecki, J.B., Bolyard, S.E., Hart, R.M., and Clark, J.M., 2014, Digital surfaces and thicknesses of selected hydrogeologic units within the Ozark Plateaus aquifer system, northwestern Arkansas: U.S. Geological Survey Scientific Investigations Report 2013-5208, 25 p., http://dx.doi.org/10.3133/sir20135208.

ISSN 2328-0328 (online) 


\section{Contents}

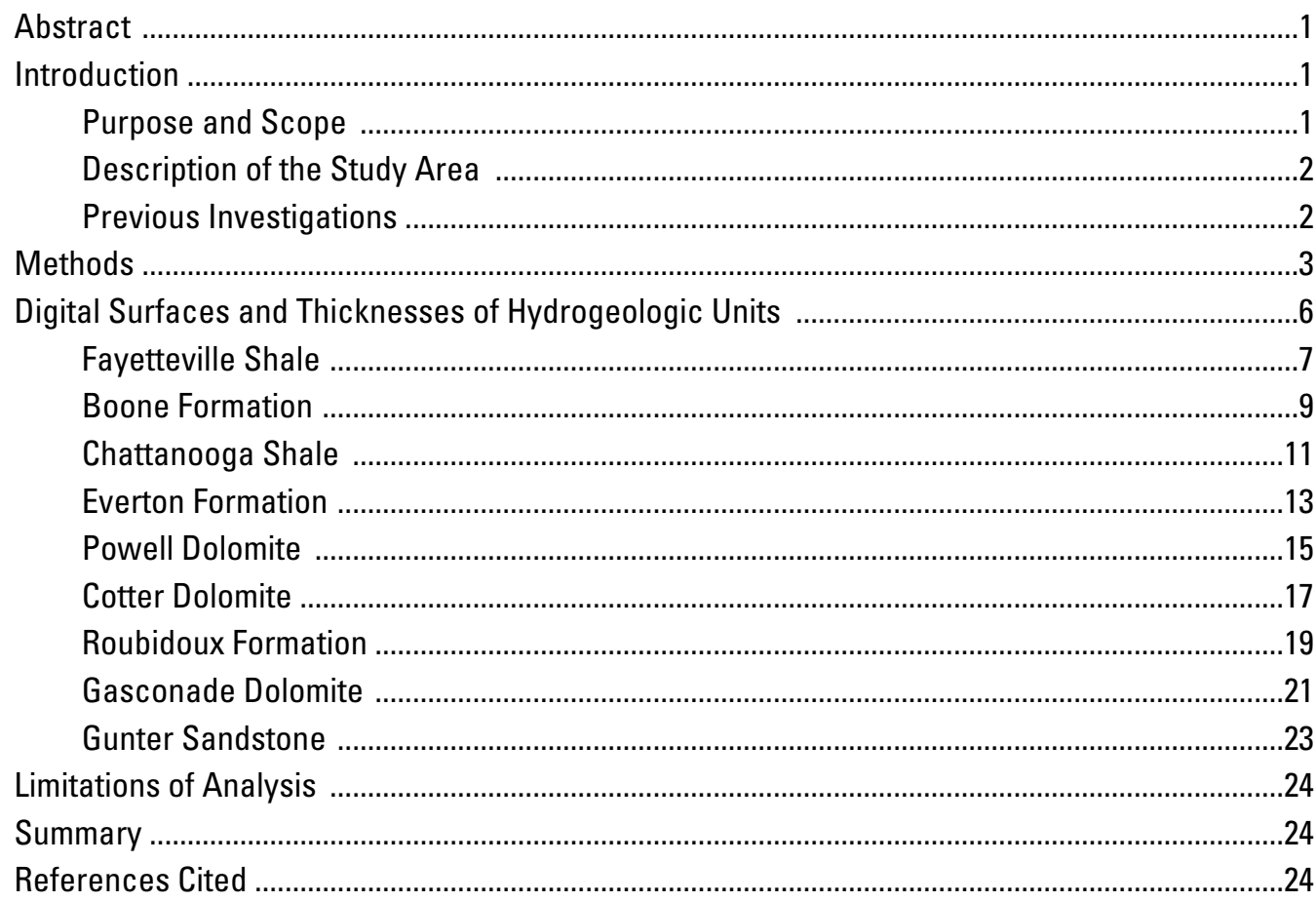

\section{Figures}

1. Map showing Ozark Plateaus aquifer system and study area .........................................

2. Map showing study area and borehole-data locations used in creating digital

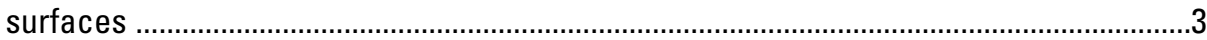

3. Example of geophysical logs with hydrogeologic picks .............................................5

4. Map showing altitude of the top of Fayetteville Shale ……................................................7

5. Map showing thickness of Fayetteville Shale ..............................................................

6. Map showing altitude of the top of Boone Formation ......................................................

7. Map showing thickness of Boone Formation ………..............................................10

8. Map showing altitude of the top of Chattanooga Shale ………..................................11

9. Map showing thickness of Chattanooga Shale ..........................................................12

10. Map showing altitude of the top of Everton Formation .................................................13

11. Map showing thickness of Everton Formation ...........................................................

12. Map showing altitude of the top of Powell Dolomite ....................................................15

13. Map showing thickness of Powell Dolomite ...............................................................16

14. Map showing altitude of the top of Cotter Dolomite ......................................................

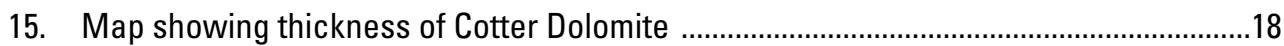

16. Map showing altitude of the top of Roubidoux Formation .............................................19

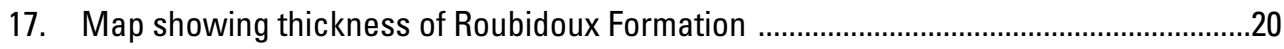

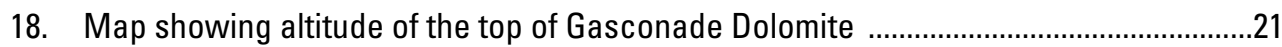

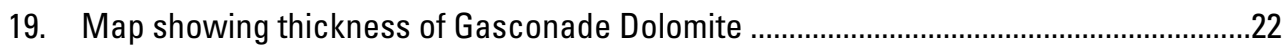

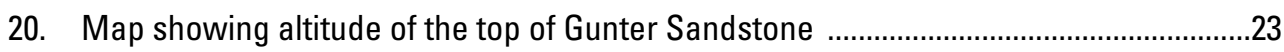




\section{Tables}

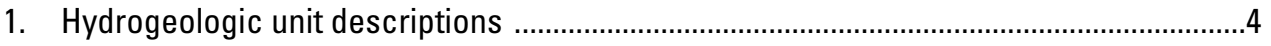

2. Statistics for the interpolation of the hydrogeologic units .............................................6

\section{Conversion Factors}

Inch/Pound to SI

\begin{tabular}{|c|c|c|}
\hline Multiply & By & To obtain \\
\hline \multicolumn{3}{|c|}{ Length } \\
\hline foot $(\mathrm{ft})$ & 0.3048 & meter $(\mathrm{m})$ \\
\hline mile (mi) & 1.609 & kilometer (km) \\
\hline \multicolumn{3}{|c|}{ Area } \\
\hline square mile $\left(\mathrm{mi}^{2}\right)$ & 2.590 & square kilometer $\left(\mathrm{km}^{2}\right)$ \\
\hline
\end{tabular}

Vertical coordinate information is referenced to the National Geodetic Vertical Datum of 1929 (NGVD 29)

Horizontal coordinate information is referenced to the North American Datum of 1983 (NAD 83) Altitude, as used in this report, refers to distance above the vertical datum. 


\title{
Digital Surfaces of Selected Hydrogeologic Units Within the Ozark Plateaus Aquifer System, Northwestern Arkansas
}

\author{
By John B. Czarnecki, Susan E. Bolyard, Rheannon M. Hart, and Jimmy M. Clark
}

\begin{abstract}
Digital surfaces and thicknesses of nine hydrogeologic units of the Ozark Plateaus aquifer system from land surface to the top of the Gunter Sandstone in northwestern Arkansas were created using geophysical logs, drillers' logs, geologistinterpreted formation tops, and previously published maps. The 6,040 square mile study area in the Ozark Plateaus Province includes Benton, Washington, Carroll, Madison, Boone, Newton, Marion, and Searcy Counties. The top of each hydrogeologic unit delineated on geophysical logs was based partly on previously published reports and maps and also from drillers' logs. These logs were then used as a basis to contour digital surfaces showing the top and thickness of the Fayetteville Shale, the Boone Formation, the Chattanooga Shale, the Everton Formation, the Powell Dolomite, the Cotter Dolomite, the Roubidoux Formation, the Gasconade Dolomite, and the Gunter Sandstone.
\end{abstract}

\section{Introduction}

The Ozark Plateaus aquifer system (fig. 1) covers a four State region located predominantly in southern Missouri, with the remainder in southeastern Kansas, northeastern Oklahoma, and northern Arkansas (Imes, 1990). Parts of this region are experiencing substantial population growth and increased usage of groundwater from the aquifers therein (Czarnecki and others, 2009). In an effort to refine the definition of hydrogeologic units within the Ozark Plateaus aquifer system in northwestern Arkansas, a hydrogeologic database was compiled of geophysical logs, drillers' logs, geologist-interpreted formation tops, and previously published and nonpublished maps. From these sources, 176 data-point locations were identified covering an area of 6,040 square miles over eight counties in Arkansas (fig. 2). The altitudes of the tops of nine hydrogeologic units were compiled and used to create digital surfaces. The nine hydrogeologic units are: the Fayetteville Shale, the Boone Formation, the Chattanooga Shale, the Everton Formation, the Powell Dolomite, the Cotter Dolomite, the Roubidoux Formation, the Gasconade Dolomite, and the Gunter Sandstone.

This study extends a hydrogeologic-unit database constructed for the Mississippi Embayment Regional Aquifer Study (MERAS) (Hart and Clark, 2008). Much larger in scope, MERAS assembled hydrogeologic data from 11 States within the Mississippi embayment. The geophysical-log database and subsequent hydrogeologic-unit database for MERAS are the foundation from which this study was initiated, with the ultimate goal of creating a hydrologic framework for the entire State of Arkansas.

\section{Purpose and Scope}

The purpose of this report is to present digital surfaces of the altitudes and thicknesses of hydrogeologic units in eight counties in northwestern Arkansas (fig. 2). The report includes a discussion of the methods used to assemble the datasets and to construct the digital surface and thickness maps. A description of the creation of the hydrogeologic database is also included.

A goal of the study associated with this report is to provide an environment to update and modify digital hydrogeologic-unit surfaces as new well logs within and outside the study area are added to the well-log database. Well-log database data include digitally scanned well-log images available to the public on the Internet, as well as specific information for each borehole location. These data are part of a statewide geophysical-log database that can be used to identify the depth and thickness of hydrogeologic units at potential new well sites. This information can be used in conjunction with the Arkansas Water-Use Data Base System (WUDBS) to assign aquifer codes based on latitude and longitude measurements determined during log location determination (see http://ar.water.usgs.gov/meras/start.php). Data from 176 boreholes were used in the current study to derive altitudes of hydrogeologic units. 


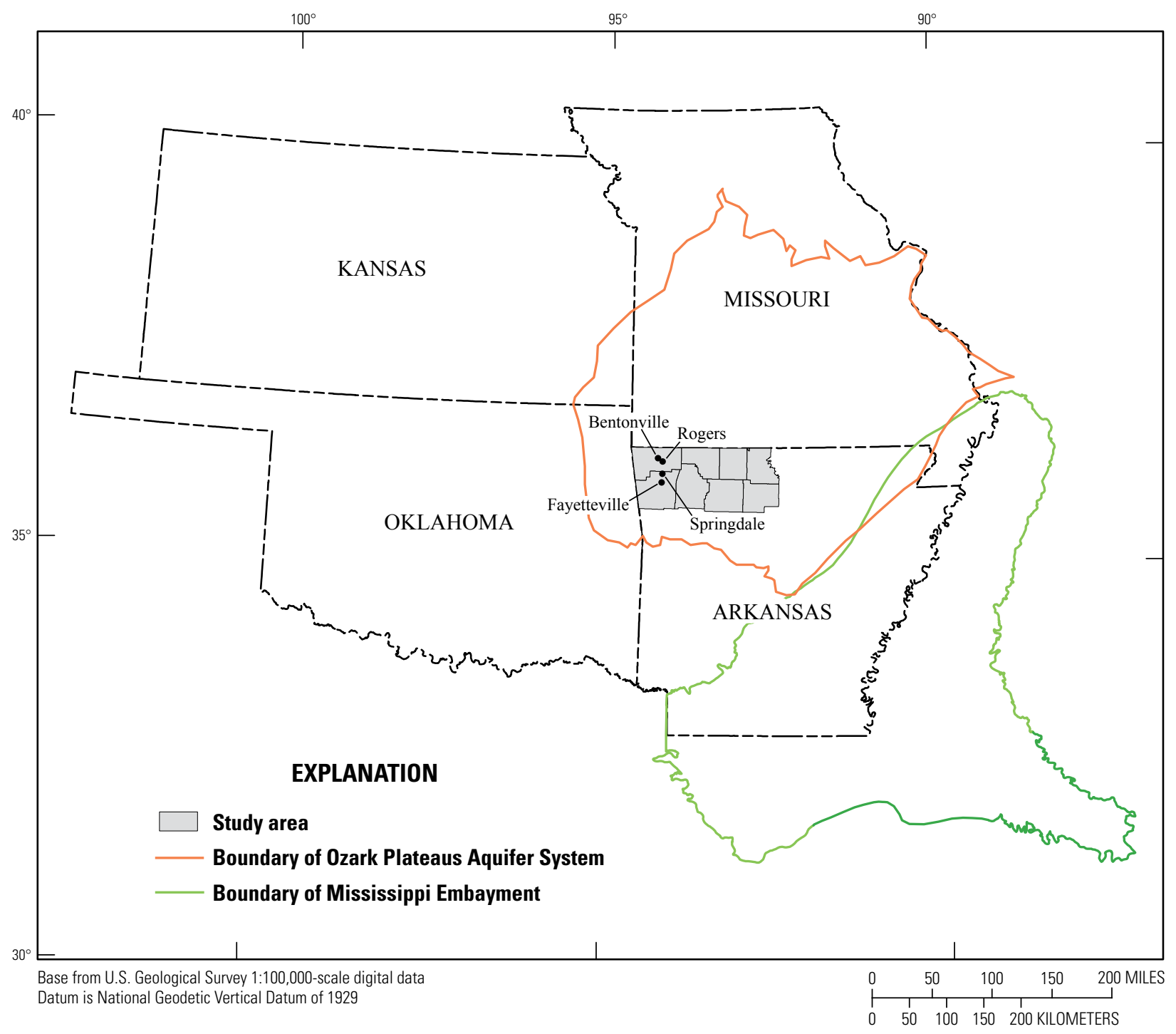

Figure 1. Ozark Plateaus aquifer system and study area. Figure modified from Czarnecki and others (2009).

\section{Description of the Study Area}

The study area comprises eight counties in northwestern Arkansas (fig. 1). These counties are: Benton, Carroll, Boone, Marion, Washington, Madison, Newton, and Searcy. Total area covered by the counties is about 6,040 square miles. The topography is variable with gently rolling hills in the northwest to more mountainous areas with substantial relief to the south of the study area. Population centers include Fayetteville, Rogers, Bentonville, and Springdale, whose water supply is Beaver Lake reservoir. Outside of these population centers, population density is sparse, particularly in the more mountainous areas. Groundwater is a source of water supply to smaller municipalities and residential users (Holland, 2007).

Rocks within the study area are generally flat lying but can exhibit substantial offset of several hundred feet because of faulting. Major faults are shown on figure 2 (Haley and others, 1993).

\section{Previous Investigations}

The methodology used to create the digital surfaces in this report is described in Hart and Clark (2008) and Hart and others (2008). Characterizations of the groundwater-flow system within the study area are presented in investigations of the Ozark Plateaus aquifer system by Imes (1990), Imes and Emmett (1994), Jorgensen (1996), and Czarnecki and others (2009). Prior and others (1999) provided generalized interpolation of lithologic surfaces and thicknesses of the Roubidoux Formation and Gunter Sandstone over the study area. Descriptions of most of the hydrogeologic units mentioned in this report are contained in McFarland (2004). 


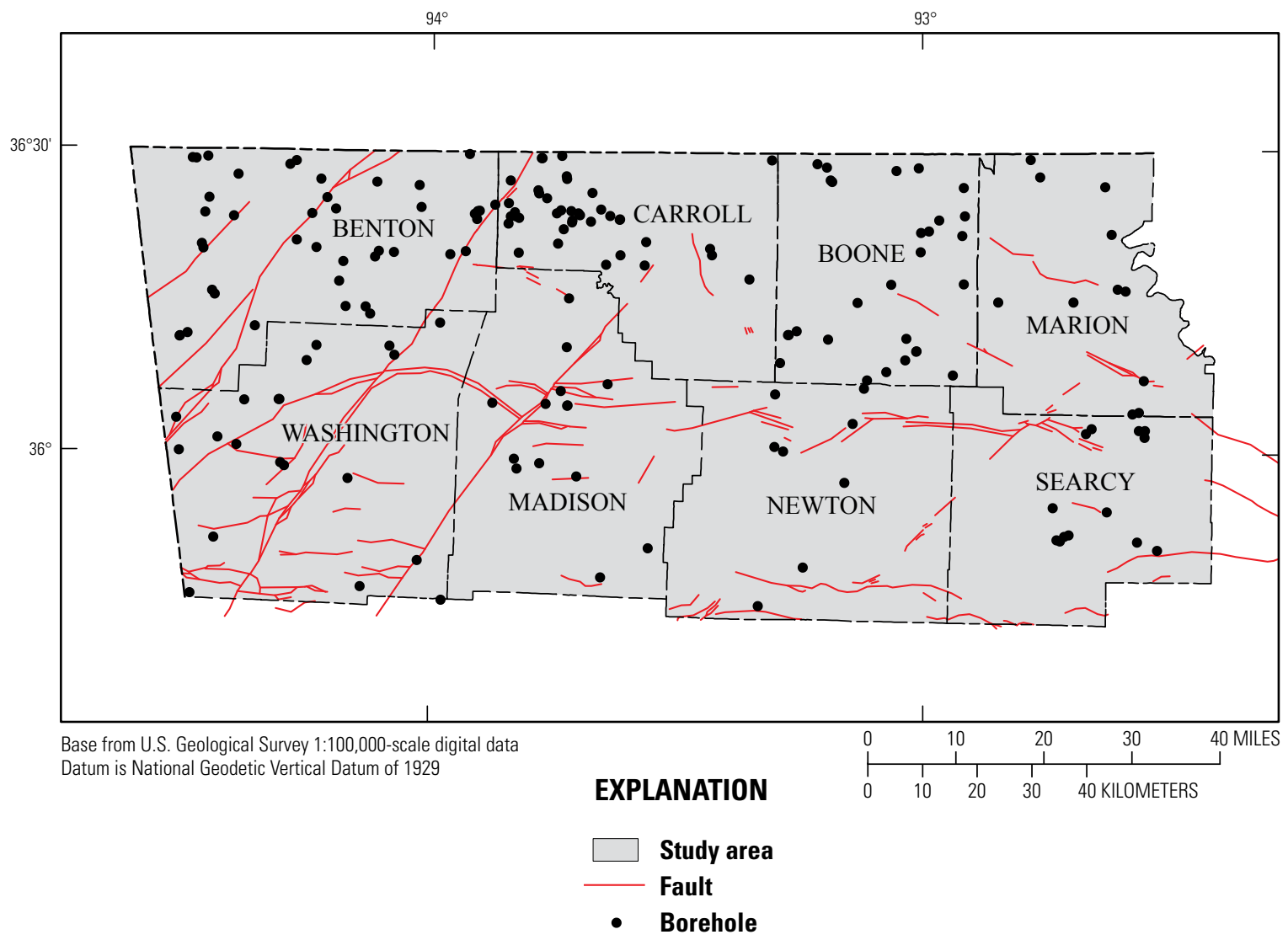

Figure 2. Study area and borehole-data locations used in creating digital surfaces.

\section{Methods}

The method used to create each digital hydrogeologic surface is that developed by Hart and others (2008). The altitudes of the tops of nine hydrogeologic units (table 1) were inferred using digitally scanned borehole geophysical logs and drillers' logs from 176 boreholes in eight counties in northwestern Arkansas (fig. 2). Borehole geophysical logs consisted of normal-resistivity, spontaneous potential, and natural-gamma logs from oil and gas test wells and domestic and municipal water-supply wells obtained from a variety of sources including the U.S. Geological Survey (USGS), the Arkansas Geological Survey, the Arkansas Department of Health, and an unpublished report (Doy L. Zachry, University of Arkansas, written commun., 2007). Geophysical logs were chosen based on their quality, total depth, and spatial distribution. When two or more logs were available at the same location, the log with greater total depth was selected for the evaluation. The altitudes of log datums were determined from information provided in the log headers, digital elevation models, USGS 7.5-minute topographic maps with an assumed accuracy of one-half the contour interval, or the USGS Ground-Water Site Inventory database (http://waterdata.usgs.gov/nwis/gwsi). Hydrogeologic surface tops for a number of boreholes used to construct the digital hydrogeologic surfaces were previously picked as part of the development of the groundwater-flow model of Imes and Emmett (1994). The inferred tops of up to nine hydrogeologic units for each borehole were used to populate a Geographic Information System (GIS) database containing information pertaining to each borehole. The availability of geophysical logs for this part of the State was limited, therefore, well drillers' and geologists' logs were used to fill in gaps in the spatial distribution of data points. For each geophysical log that was used, altitudes of the tops of formations were picked and labeled based on contrasts in geophysical-log values (fig. 3). Well drillers' cuttings logs were obtained from the Arkansas Geological Survey and from geologist-interpreted formation tops from Sheldon (1954). 
Table 1. Hydrogeologic unit descriptions.

[Only hydrogeologic units with digital surfaces in this report are listed. Description information from Imes and Emmett, 1994; McFarland, 2004; Pugh, 2008; Czarnecki and others, 2009; U.S. Geological Survey, 2012]

\begin{tabular}{|c|c|c|c|}
\hline $\begin{array}{c}\text { Geologic } \\
\text { unit name }\end{array}$ & $\begin{array}{l}\text { Geologic } \\
\text { age }\end{array}$ & $\begin{array}{l}\text { Hydrogeologic } \\
\text { unit }\end{array}$ & Description \\
\hline $\begin{array}{c}\text { Fayetteville } \\
\text { Shale }\end{array}$ & $\begin{array}{l}\text { Late } \\
\qquad \text { Mississipian }\end{array}$ & $\begin{array}{l}\text { Western Interior } \\
\text { Plains } \\
\text { confining unit }\end{array}$ & $\begin{array}{l}\text { Chiefly a black shale but also may be bluish or even yellowish-brown. Has many } \\
\text { concretions that break up into prismatic fragments. Reported thickness ranges from } \\
10 \text { to } 400 \text { feet. Exhibits very small permeability as a confining unit. }\end{array}$ \\
\hline $\begin{array}{l}\text { Boone } \\
\text { Formation }\end{array}$ & $\begin{array}{l}\text { Early } \\
\quad \text { Mississipian }\end{array}$ & $\begin{array}{l}\text { Springfield } \\
\text { Plateau } \\
\text { aquifer }\end{array}$ & $\begin{array}{l}\text { Characterized by layers of limestone, usually hard, compact, and gray, interbedded } \\
\text { with chert, white or gray on freshly broken surface but becoming brownish on } \\
\text { exposure. Thickness ranges from } 150 \text { to } 200 \text { feet in Washington County, Arkansas. } \\
\text { Exhibits moderate to large permeability as a substantial aquifer. Water production } \\
\text { occurs along bedding planes, fractures, and joints. }\end{array}$ \\
\hline $\begin{array}{l}\text { Chattanooga } \\
\text { Shale }\end{array}$ & $\begin{array}{l}\text { Early } \\
\text { Mississippian } \\
\text { to Middle } \\
\text { Devonian }\end{array}$ & $\begin{array}{l}\text { Ozark confining } \\
\text { unit }\end{array}$ & $\begin{array}{l}\text { Typically a black, fissile clay shale that weathers into thin flakes. The beds are usually } \\
\text { cut by prominent joints creating polygonal blocks upon weathering. The upper } \\
\text { part of the formation may be slightly sandy and usually contains abundant pyrite. } \\
\text { Reported thickness of the Chattanooga Shale (including the Sylamore Sandstone) } \\
\text { ranges from } 0 \text { to about } 85 \text { feet but normally averages about } 30 \text { feet. Exhibits very } \\
\text { small permeability as a confining unit. }\end{array}$ \\
\hline $\begin{array}{l}\text { Everton } \\
\text { Formation }\end{array}$ & $\begin{array}{l}\text { Middle } \\
\quad \text { Ordovician }\end{array}$ & Ozark aquifer & $\begin{array}{l}\text { Consists of a light- to medium-brown, micritc to coarsely crystalline, sandy dolomite. } \\
\text { Reported thickness ranges from } 0 \text { to } 240 \text { feet. Exhibits moderate permeability as an } \\
\text { aquifer. }\end{array}$ \\
\hline $\begin{array}{l}\text { Powell } \\
\text { Dolomite }\end{array}$ & $\begin{array}{l}\text { Early } \\
\quad \text { Ordovician }\end{array}$ & Ozark aquifer & $\begin{array}{l}\text { Consists of light-gray to greenish-gray magnesian limestone with some shale and } \\
\text { locally a bed of limestone conglomerate at base. Unconformably underlies Everton } \\
\text { Limestone; unconformably overlies Cotter Dolomite. Reported thickness ranges } \\
\text { from } 0 \text { to } 200 \text { feet. Exhibits moderate permeability as an aquifer. }\end{array}$ \\
\hline $\begin{array}{l}\text { Cotter } \\
\text { Dolomite }\end{array}$ & $\begin{array}{l}\text { Early } \\
\quad \text { Ordovician }\end{array}$ & Ozark aquifer & $\begin{array}{l}\text { Light-gray to brown, cherty dolomite. Consists of two kinds of dolomite: a white } \\
\text { to buff or gray, fine-grained, argillaceous, earthy textured, relatively soft variety } \\
\text { known as "cotton rock"; and a gray, medium-grained, more massive variety } \\
\text { that weathers hackly on the surface and becomes dark upon exposure. Contains } \\
\text { some chert and a little interbedded saccharoidal sandstone and green shale. } \\
\text { Unconformably underlies Powell Dolomite. Reported thickness is } 500 \text { feet or } \\
\text { greater. Exhibits moderate permeability as an aquifer. }\end{array}$ \\
\hline $\begin{array}{l}\text { Gasconade } \\
\text { Dolomite }\end{array}$ & $\begin{array}{l}\text { Early } \\
\quad \text { Ordovician }\end{array}$ & Ozark aquifer & $\begin{array}{l}\text { Consists of a great series of dolomite beds interstratified with thin beds of sandstone. } \\
\text { Reported thickness data unavailable for study area. Exhibits moderate permeability } \\
\text { as an aquifer. }\end{array}$ \\
\hline $\begin{array}{l}\text { Gunter } \\
\text { Sandstone }\end{array}$ & $\begin{array}{l}\text { Early } \\
\text { Ordovician }\end{array}$ & Ozark aquifer & $\begin{array}{l}\text { White to gray quartz sandstone. Maximum reported thickness is about } 100 \text { feet. } \\
\text { Exhibits moderate permeability as an aquifer. }\end{array}$ \\
\hline
\end{tabular}




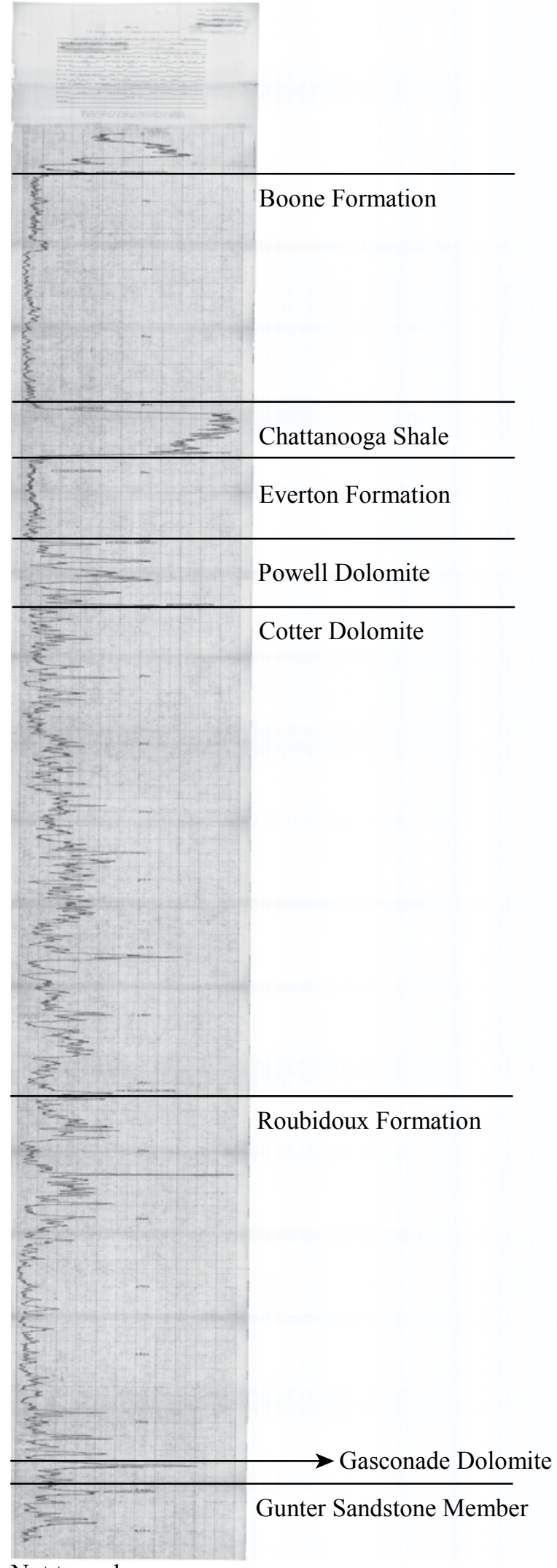

Not to scale

Figure 3. Example of geophysical logs with hydrogeologic picks (not to scale).
The interpolation method used to create each hydrogeologic surface from the individual borehole data was based on the Australian National University Digital Elevation Model (ANUDEM) procedure developed by Hutchinson (1989). The ANUDEM procedure was designed principally to interpolate scattered surface-specific point-altitude data and to remove spurious sinks within the data without oversmoothing well-defined surface features (Hutchinson, 1989). The ANUDEM algorithm is implemented in the TopoToRaster_3d tool contained in ArcGIS (Environmental Systems Research Institute, 2012). The altitude of the top of a unit was constrained to land surface as determined from DEM data in areas where the unit outcropped. Most of the nine units occurred throughout the eight-county region; however, the Fayetteville Shale, Boone Formation, and Chattanooga Shale did not extend throughtout the region so maps were cropped in areas where these units were absent. Cropping outlines were based on mapped extents of hydrogeologic units on the Arkansas State geologic map (Haley and others, 1993). Because the interpolation method used to construct the digital surface can produce high or low areas that are not supported by control points, adjustments to the surfaces were made to prevent an interpolated surface from intersecting with or passing through an underlying surface. There are various reasons why surfaces might intersect or cross, but the primary reason is because of differences in the numbers of points used to interpolate each surface. If the altitudes of points within an interpolated surface were at or below the interpolated surface of the surface below it, points in the overlying surface were set equal to the underlying surface plus $10 \mathrm{ft}$. The resultant corrected raster surfaces were used to calculate the thickness of each unit shown in this report. Each hydrogeologic unit dataset contains 123 rows and 55 columns representing interpoloated surface altitudes and thicknesses at 1-mile grid spacing. In general, limitations of data interpolation included areas of sparse geophysical log control points, log datums not clearly defined for some logs, unknown exact extent of each hydrogeologic unit in subcrop, interpolation limitations, large offsets of hydrogeologic units because of faulting, and values averaged over 1-mile grid spacing.

The GIS database that was created for this study allows for the addition of surface-elevation data from boreholes within or outside the study area as these data become available. The same procedures described above can then be used to extend or refine the digital surfaces using additional data. Digital surfaces are based solely on the inferred picks of altitude tops contained in the GIS database and do not include any adjustments for structural controls such as faults that would cause abrupt displacement along the digital surface.

For the purposes of this report, the current digital surfaces and thicknesses of the hydrogeologic units are considered to be version 1.0. A version number may be helpful to track future updates of the interpretation of the hydrogeologic unit tops as more data are acquired and the overall understanding of the subsurface changes. Hydrogeologic unit datasets are downloadable in grid ASCII format (http://pubs.usgs.gov/ sir/2013/5208/). 


\section{Digital Surfaces and Thicknesses of Hydrogeologic Units}

Digital surface altitude and thickness maps created using the ANUDEM procedure described previously are presented in figures 4-20. Altitudes of all units tend to be higher toward the north and lower in the south and southeast parts of the study area. Altitude of land surface was taken into account during the creation or adjustment of the digital surfaces of the Fayetteville Shale, Boone Formation, and the Chattanooga Shale. The altitude and thickness maps of the Fayetteville Shale (figs. 4 and 5), Boone Formation (figs. 6 and 7), and Chattanooga Shale (figs. 8 and 9) are spatially discontinuous in the study area because of erosion of these units. Comparison of the extent of the units can be made using geologic maps provided by the Arkanasas Geological Survey (http://www.geology.ar.gov/catalog/geologic_maps.htm).
The general altitudes of tops and thicknesses of units are presented on maps at a contour interval of $200 \mathrm{ft}$ so as not to imply an accuracy that cannot be supported given the sparseness of the boreholes and uncertainty in the digital raster surfaces used to create the altitude and thickness maps. Subsequent sections in this report provide a general description of the nine hydrogeologic units, together with discussion of their altitude, thickness, and areal extent.

Statistics for the fit between the interpolated digital hydrogeologic-unit surfaces and the points used to create them are listed in table 2. Large differences typically occur in the vicinity of faults or where few data points are available for interpolation. These large differences help to explain the large differences in thicknesses reported here compared to previously reported thicknesses. Some of the older data used in previous investigations were not available for this study, which may explain differences between those surfaces and the ones reported here.

Table 2. Statistics for the interpolation of the hydrogeologic units.

[Count refers to the number of data points used in the statistical calculations of altitude. Mean differences (correlation altitude on the geophysi $\neg$ cal logs minus interpolated digital hydrogeologic surface altitude) is the average difference between the unit correlation altitudes on the geo $\neg$ physical logs and the altitudes of the interpolated digital hydrogeologic surfaces at the location of the geophysical log control point. Minimum and maximum differences are those measured between the unit correlation altitudes on the geophysical logs and the altitudes of the interpolated digital hydrogeologic surfaces; absolute mean error is the mean of the absolute differences between the unit correlation altitudes on the geophysical logs and the altitudes of the interpolated digital hydrogeologic surfaces; negative altitudes are below the National Geodetic Vertical Datum of 1929]

\begin{tabular}{lccccccc}
\hline $\begin{array}{c}\text { Hydrogeologic } \\
\text { unit }\end{array}$ & Count & $\begin{array}{c}\text { Minimum } \\
\text { difference } \\
\text { (feet) }\end{array}$ & $\begin{array}{c}\text { Maximum } \\
\text { difference } \\
\text { (feet) }\end{array}$ & $\begin{array}{c}\text { Mean } \\
\text { difference } \\
\text { (feet) }\end{array}$ & $\begin{array}{c}\text { Absolute } \\
\text { mean error } \\
\text { (feet) }\end{array}$ & $\begin{array}{c}\text { Minimum } \\
\text { interpolated } \\
\text { altitude } \\
\text { (feet) }\end{array}$ & $\begin{array}{c}\text { Maximum } \\
\text { interpolated } \\
\text { altitude } \\
\text { (feet) }\end{array}$ \\
\hline Fayetteville Shale & 8 & -2.79 & 10.65 & 1.69 & 2.64 & 764 & 1,829 \\
Boone Formation & 58 & -525.86 & 247.91 & 17.18 & 37.57 & 545 & 1,757 \\
Chattanooga Shale & 67 & -613.95 & 49.95 & -35.83 & 45.40 & 346 & 1,619 \\
Everton Formation & 96 & -475.89 & 104.15 & -38.89 & 57.54 & 272 & 1,476 \\
Powell Dolomite & 98 & -404.58 & 158.96 & -4.27 & 22.28 & -436 & 1,466 \\
Cotter Dolomite & 110 & -91.42 & 86.42 & 5.83 & 15.95 & -655 & 1,426 \\
Roubidoux Formation & 111 & -578.77 & 88.10 & -21.81 & 39.57 & $-1,189$ & 1,221 \\
Gasconade Dolomite & 45 & -78.69 & 63.23 & 1.70 & 13.50 & $-1,173$ & 1,001 \\
Gunter Sandstone & 38 & -57.04 & 21.12 & -12.02 & 13.89 & $-2,111$ & 820 \\
\hline
\end{tabular}




\section{Fayetteville Shale}

The Fayetteville Shale of Late Mississippian age is a black shale but also may be bluish or even yellowish-brown. Arkansas Geological Survey (2012) describes the Fayetteville Shale as

“... a black, fissile, concretionary, clay shale.

Dark-gray, fine-grained limestones commonly are interbedded with the shales in north-central Arkansas. The Wedington Sandstone Member, known from west Arkansas outcrops, is composed of gray to brown, fine-grained, sometimes calcareous sandstone. Septarian concretions are common in lower beds of the Fayetteville Shale, but may be found throughout the formation. Fossils are abundant in some intervals and in local areas. Most of the fauna recovered is pyritic, but some silicified material is found. The formation is considered to rest conformably on the Batesville Sandstone (and Hindsville Member). The Fayetteville Shale ranges in thickness from 10 to 400 feet."

In central Arkansas, the Fayetteville Shale is a reservoir for natural gas production (Kresse and others, 2012).

Altitudes of the top of the Fayetteville Shale in the study area are interpolated using the digital surface to be between 764 and 1,829 ft (fig. 4). Thickness of the Fayetteville Shale (fig. 5) is between 0 and $716 \mathrm{ft}$ in the study area.

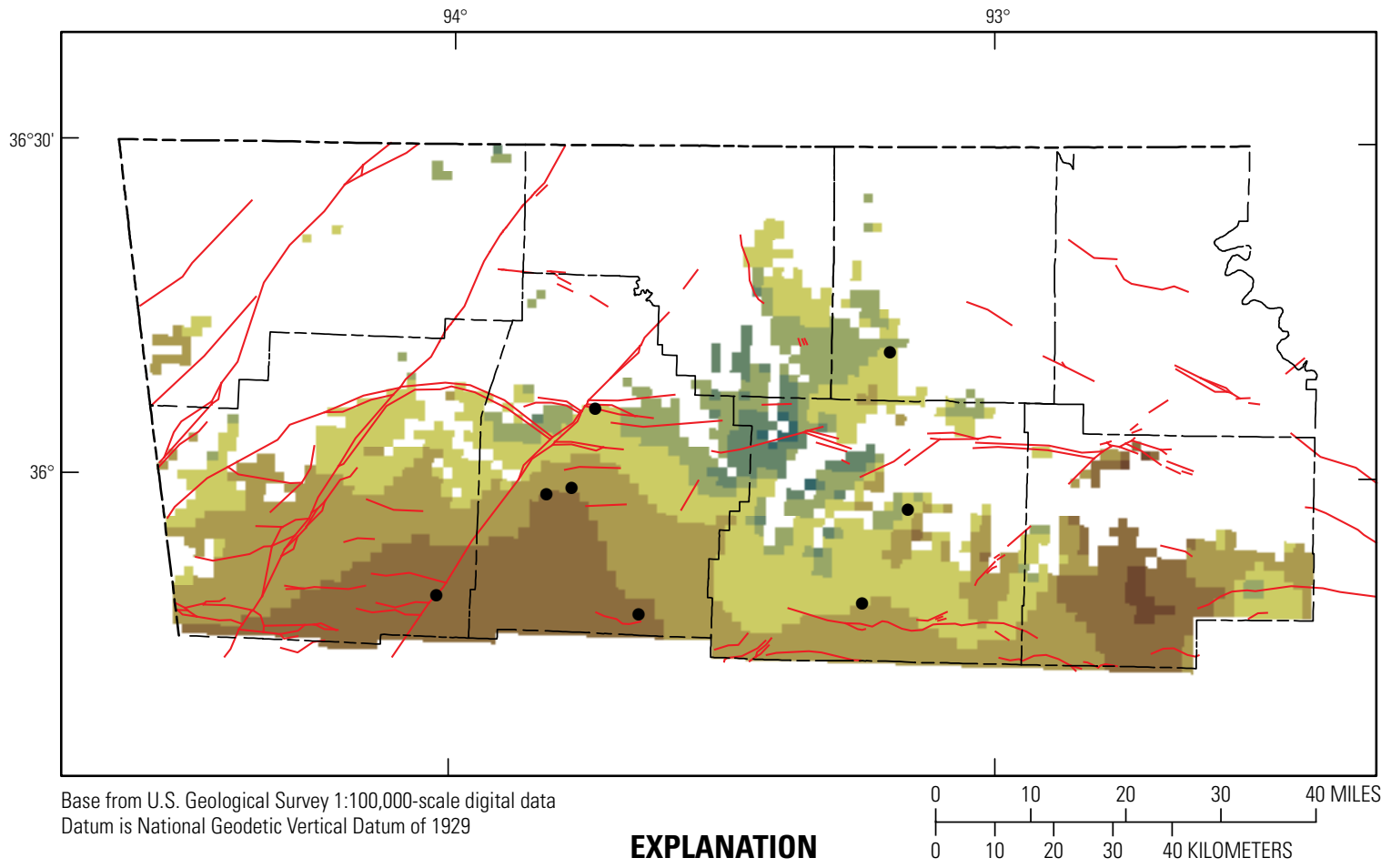

Altitude of formation top, in feet

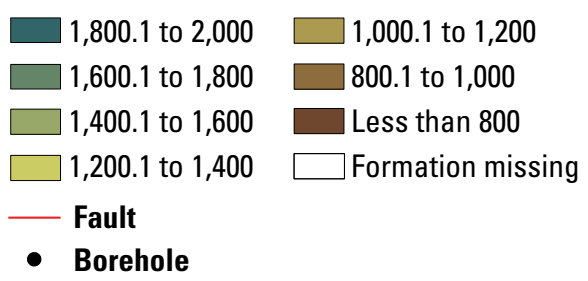

Figure 4. Altitude of the top of Fayetteville Shale. 


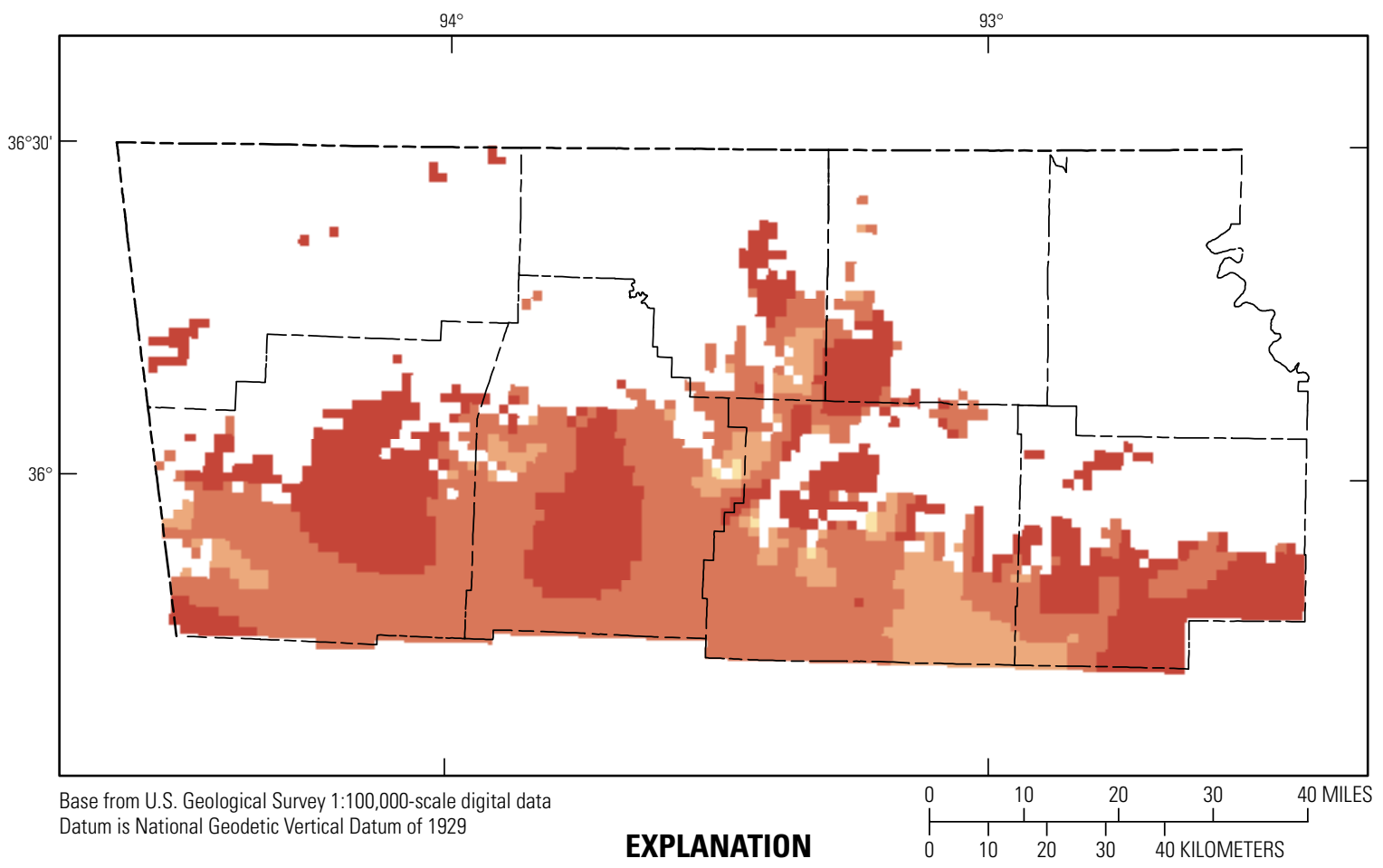

Thickness of formation, in feet

600.1 to $800 \quad \square 200$ or less
400.1 to $600 \quad \square$ Formation missing
200.1 to 400

Figure 5. Thickness of Fayetteville Shale. 


\section{Boone Formation}

The Boone Formation of Early Mississippian age is characterized by layers of hard, compact, and gray limestone, interbedded with chert, white or gray on freshly broken surface but becoming brownish on exposure. The Arkansas Geological Survey (2012) describes the Boone Formation as

“...consisting of gray, fine- to coarse-grained fossiliferous limestone interbedded with chert. Some sections may be predominantly limestone or chert. The cherts are dark in color in the lower part of the sequence and light in the upper part. The quantity of chert varies considerably both vertically and horizontally. The Boone Formation is well known for dissolutional features, such as sinkholes, caves, and enlarged fissures. The thickness of the Boone Formation is 300 to 350 feet in most of northern Arkansas, but as much as 390 feet has been reported."

Altitudes of the top of the Boone Formation in the study area are interpolated using the digital surface to be between 545 and 1,757 ft (fig. 6). Thickness of the Boone Formation (fig. 7) is between 0 and $490 \mathrm{ft}$ in the study area.

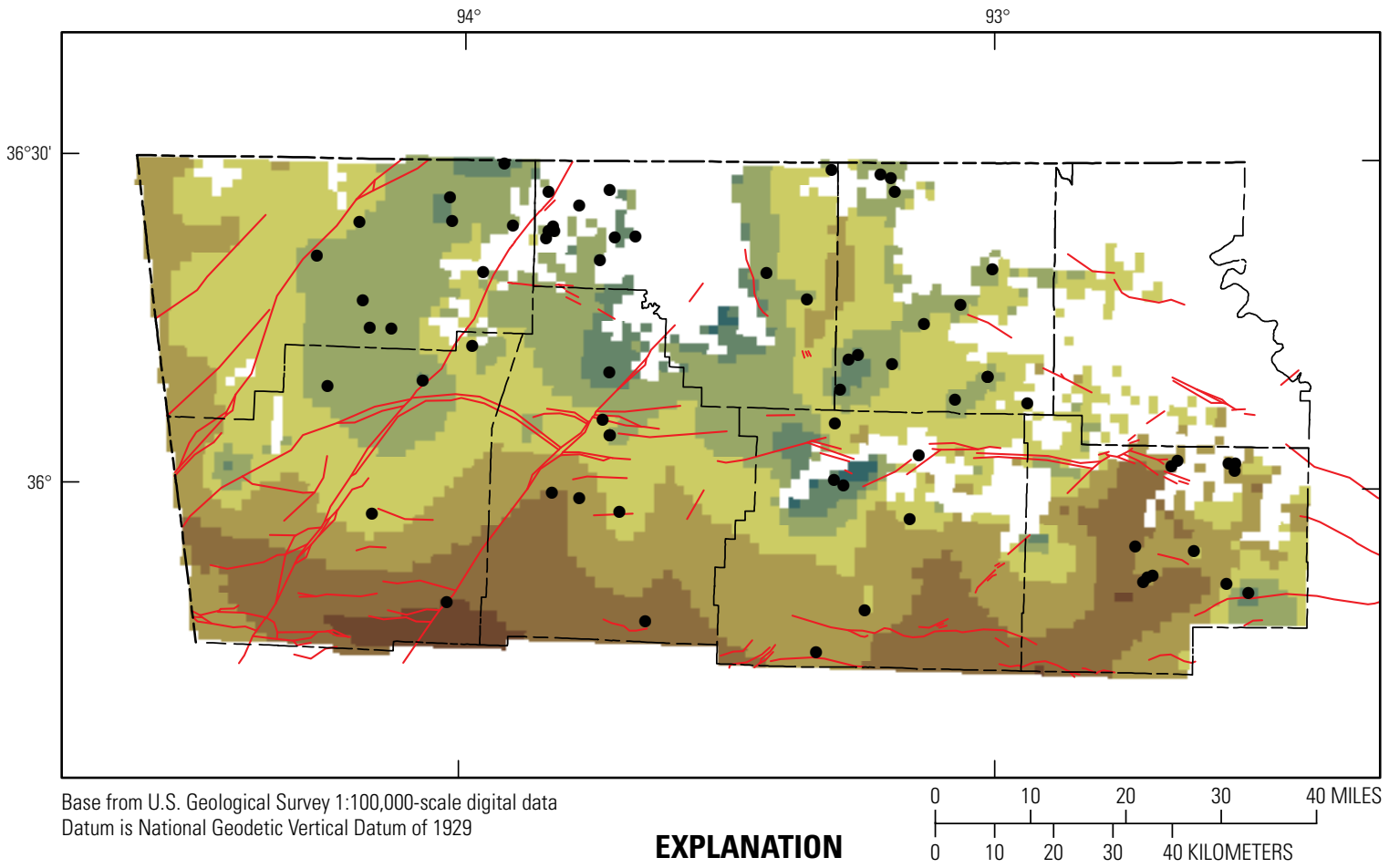

Altitude of formation top, in feet

\begin{tabular}{l}
\hline 1,600.1 to 1,800 \\
\hline 1,400.1 to 1,600 \\
\hline 1,200.1 to 1,400 \\
$\square$ 1,000.1 to 1,200 \\
- Fault \\
- Borehole
\end{tabular}

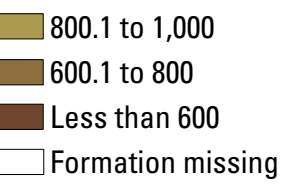

Figure 6. Altitude of the top of Boone Formation. 


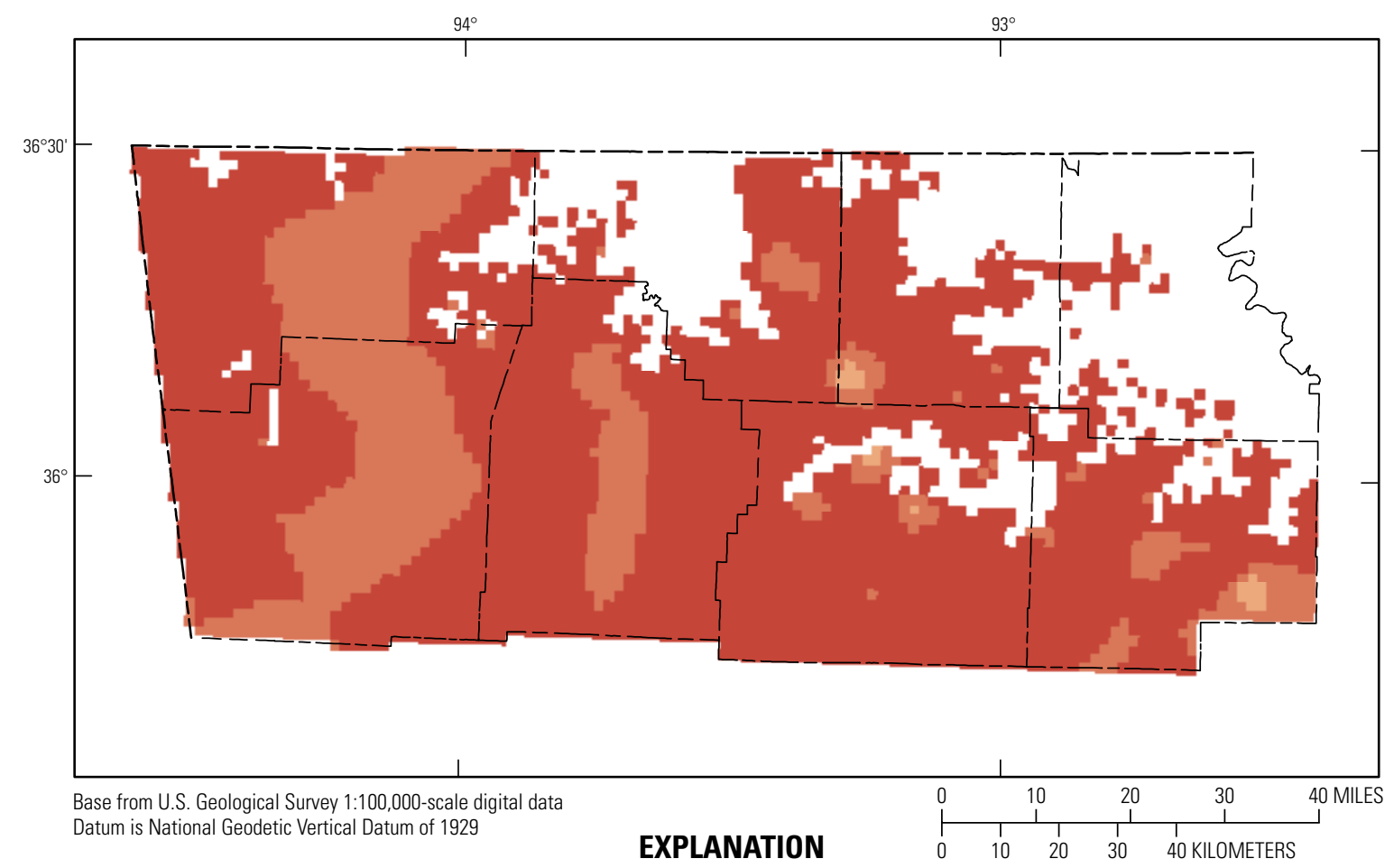

Thickness of formation, in feet

400.1 to $600 \square 200$ or less

200.1 to $400 \square$ Formation missing

Figure 7. Thickness of Boone Formation. 


\section{Chattanooga Shale}

The Chattanooga Shale of Early Mississippian to Middle Devonian age is characterized chiefly as a black, fissile clay shale that weathers into thin flakes. The Arkansas Geological Survey (2012) describes the Chattanooga Shale consisting of

“... beds [that] are usually cut by prominent joints creating polygonal blocks upon weathering. The upper part of the formation may be slightly sandy and usually contains abundant pyrite. The Chattanooga Shale is all Devonian in Arkansas."

Reported thickness of the Chattanooga Shale in northern Arkansas varies between 300 to $390 \mathrm{ft}$ (McFarland, 2004).

Altitudes of the top of the Chattanooga Shale in the study area are interpolated using the digital surface to be between 346 and 1,619 ft (fig. 8). Thickness of the Chattanooga Shale (fig. 9) is between 0 and $753 \mathrm{ft}$ in the study area.

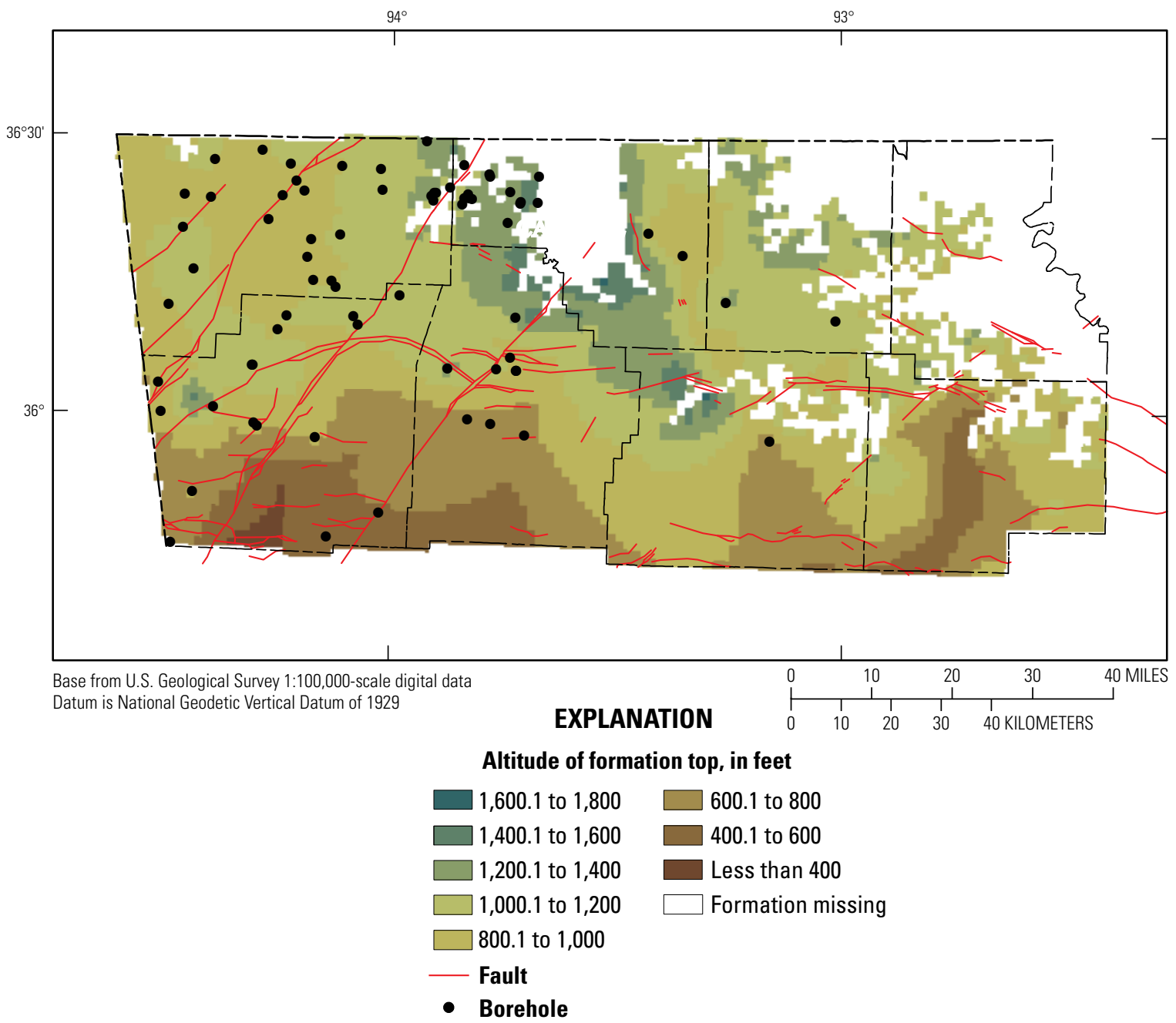

Figure 8. Altitude of the top of Chattanooga Shale. 


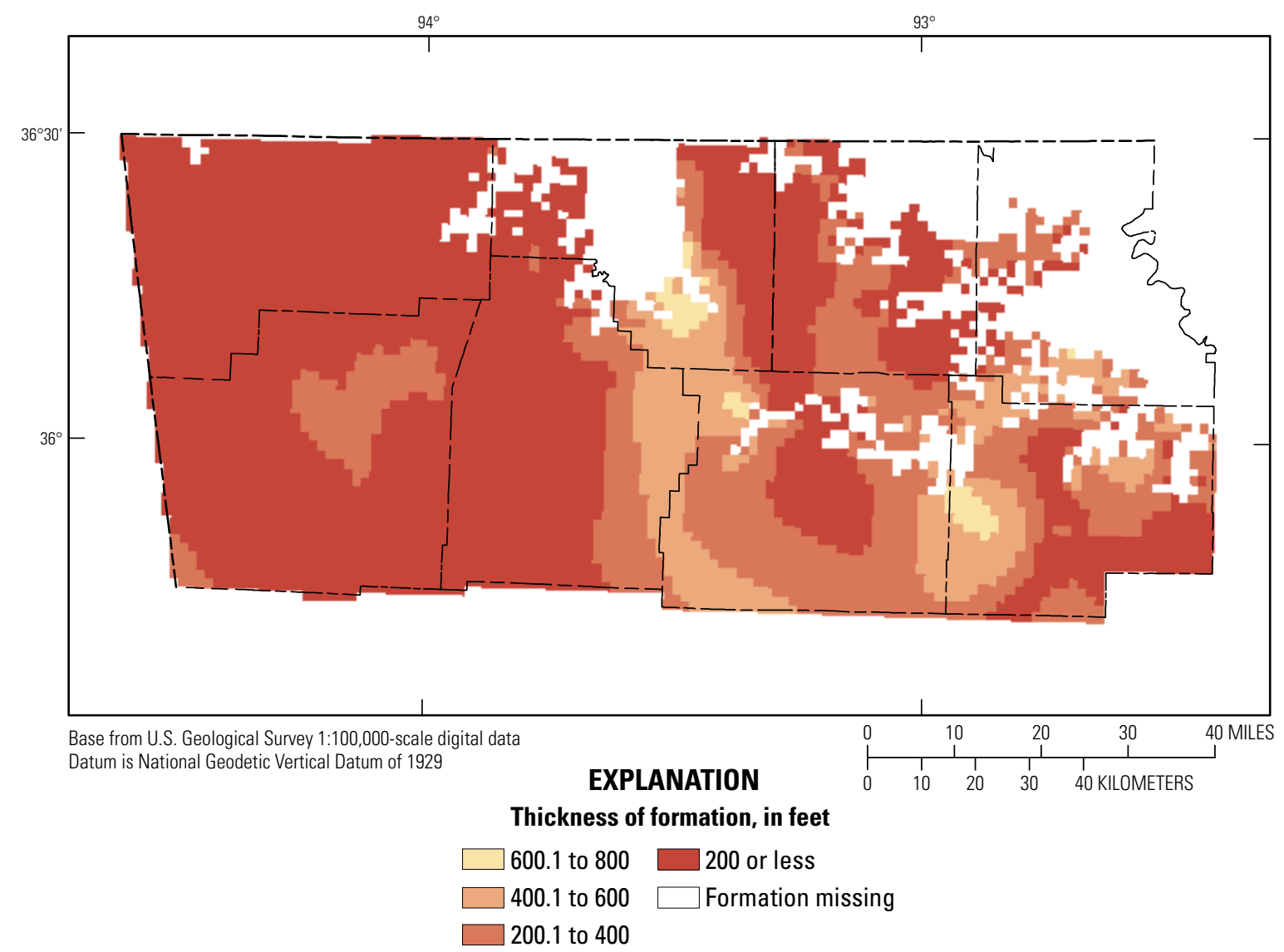

Figure 9. Thickness of Chattanooga Shale. 


\section{Everton Formation}

The Everton Formation of Middle Ordovician age shows considerable differences in lithologic character from one place to another. The Arkansas Geological Survey (2012) describes the Everton Formation as

“...composed of various mixtures of dolostone, sandstone, and limestone. The formation also has traces of conglomerate, shale, and chert in limited areas. The limestones are light-gray to brownishgray and are generally more or less dolomitic and sandy. The dolostones are light- to dark-gray and generally more or less limy and sandy. The Everton
Formation has thick members of friable, sandstone dominating local sections in the different regions. ... The lower contact is unconformable and other disconformities occur within the formation. The thickness of the Everton Formation varies from about 300 feet to as much as 650 feet."

Reported thickness of the Everton Formation (including the Sylamore Sandstone) ranges from 0 to about $85 \mathrm{ft}$, but normally averages about $30 \mathrm{ft}$ (McFarland, 2004).

Altitudes of the top of the Everton Formation in the study area are interpolated using the digital surface to be between 272 and 1,476 ft (fig. 10). Thickness of the Everton Formation (fig. 11) is between 0 and $1,432 \mathrm{ft}$ in the study area.



Figure 10. Altitude of the top of Everton Formation. 


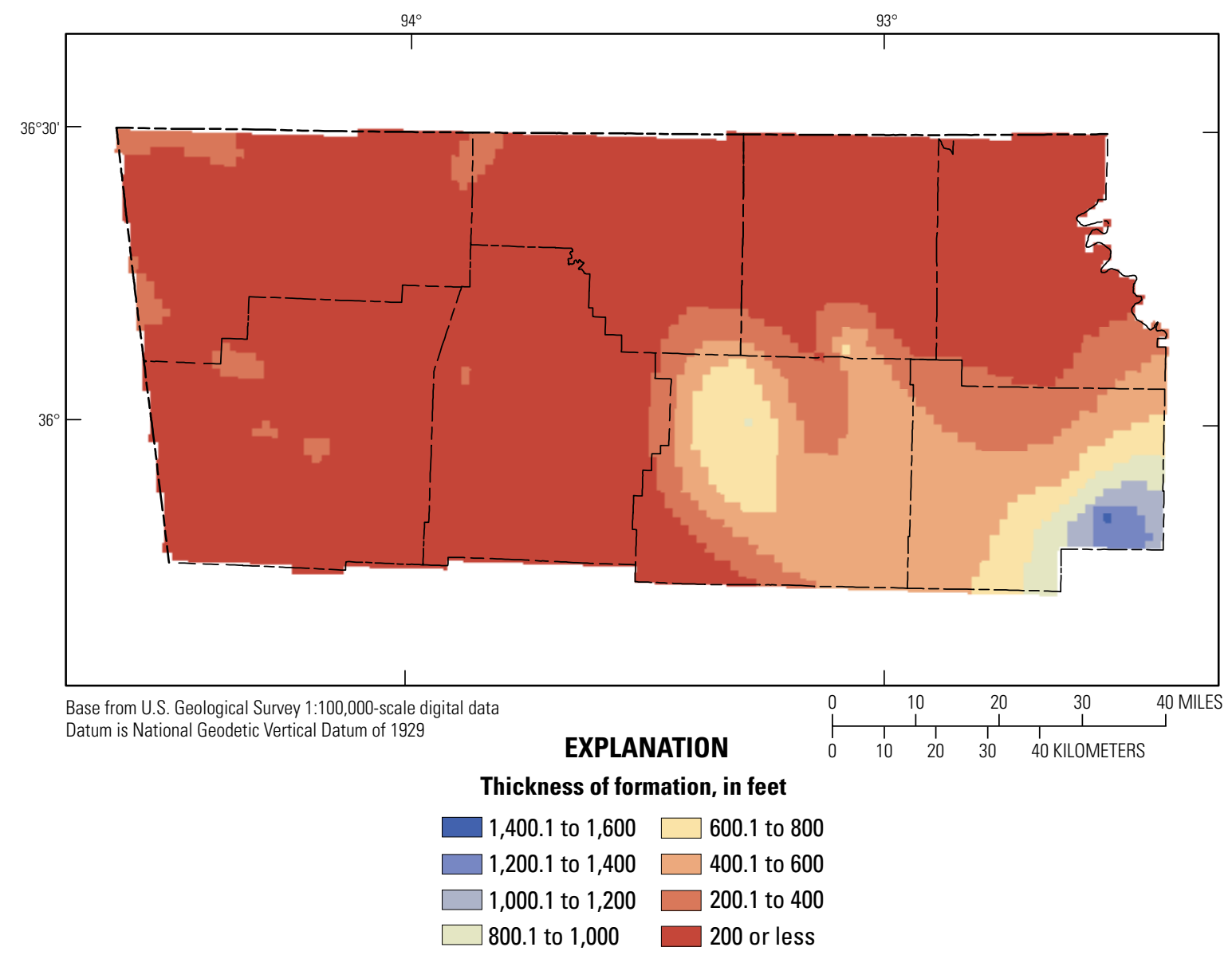

Figure 11. Thickness of Everton Formation. 


\section{Powell Dolomite}

The Powell Dolomite of Early Ordovician age is characterized as a light-gray to greenish-gray magnesian limestone with some shale and locally a bed of limestone conglomerate at its base. Arkansas Geological Survey (2012) describes the Powell Dolomite as

“... a fine-grained, light-gray to greenish-gray, limy, argillaceous dolostone with thin beds of shale, sandstone, sandy dolostone, and occasionally chert. In the lower half of the formation a dark massive ledge with abundant drusy quartz has been located in many areas. A conglomerate occurs at the base of the formation in most places. The Powell Dolomite is not known to contain many fossils, although gastropods, cephalopods, and trilobites have been reported. The lower contact with the Cotter [Dolomite] is disconformable. The formation's thickness may be as much as 215 feet, but is often much thinner."

Altitudes of the top of the Powell Dolomite in the study area are interpolated using the digital surface to be between $-436 \mathrm{ft}$ and 1,466 ft (fig. 12). Thickness of the Powell Dolomite (fig. 13) is between 0.5 and $559 \mathrm{ft}$ in the study area.

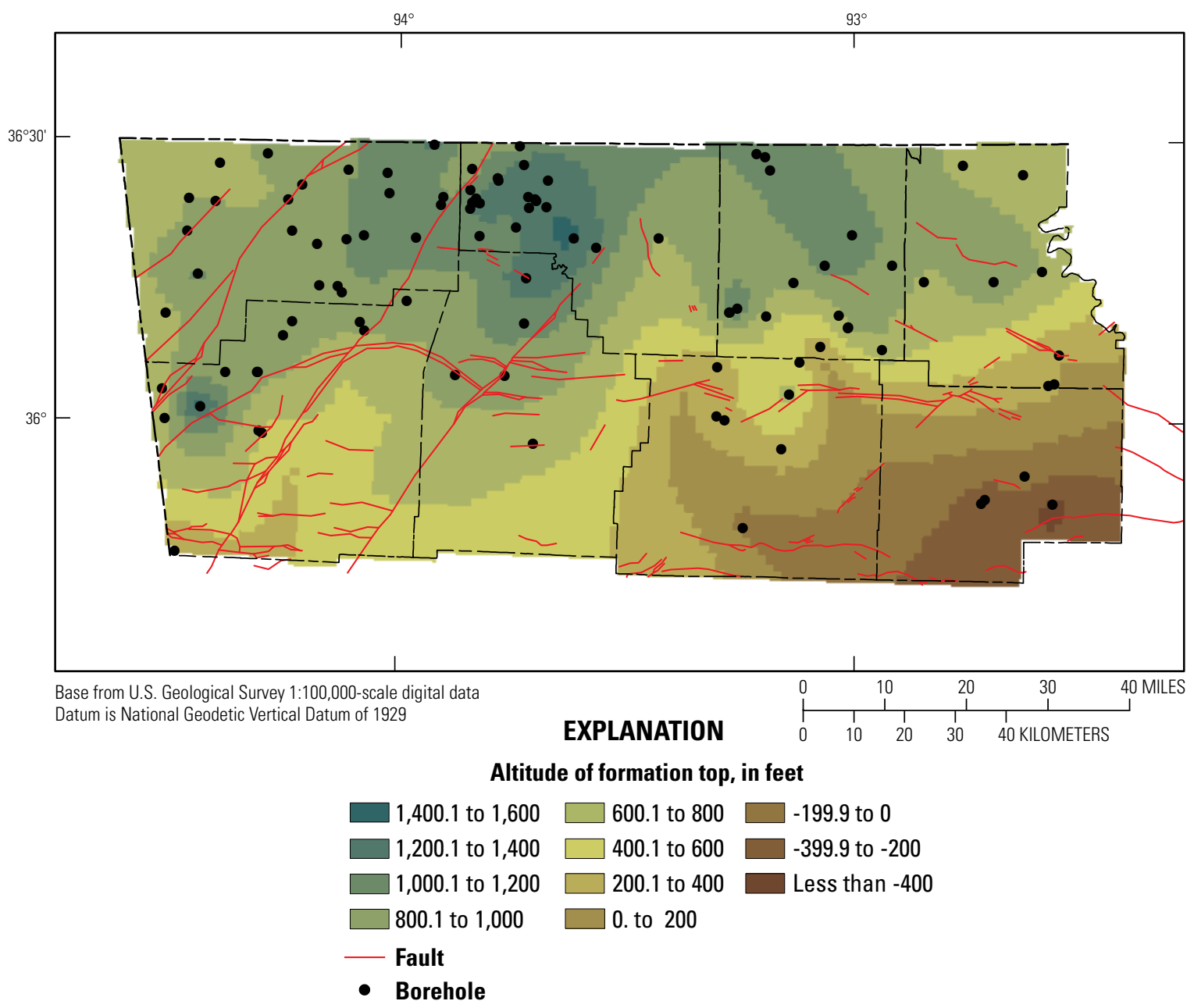

Figure 12. Altitude of the top of Powell Dolomite. 


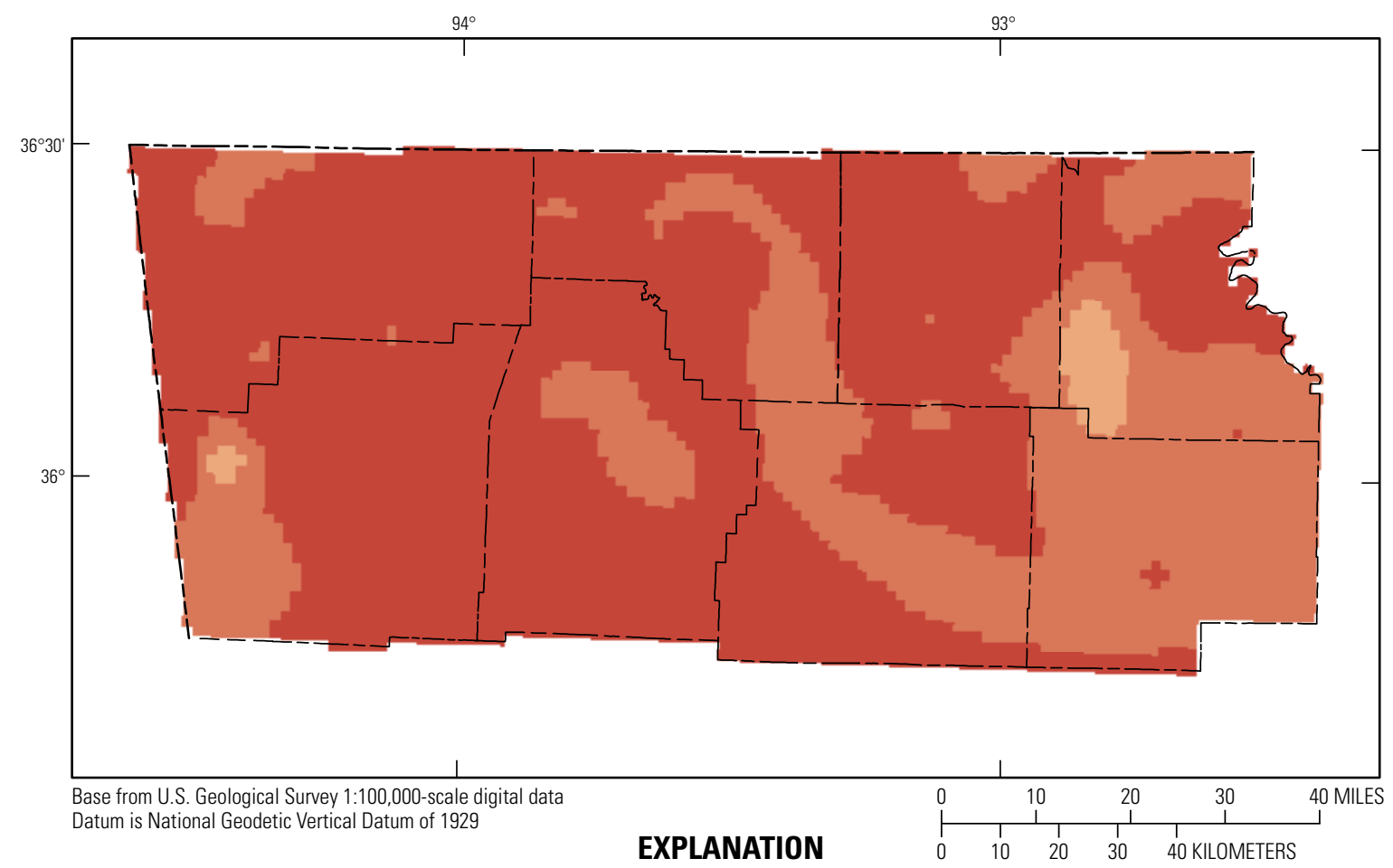

Thickness of formation, in feet

$\square 400.1$ to $600 \square 200$ or less

200.1 to 400

Figure 13. Thickness of Powell Dolomite. 


\section{Cotter Dolomite}

The Cotter Dolomite of Early Ordovician age is characterized by the Arkansas Geological Survey (2012) as a

"dolostone of predominantly two types: a finegrained, argillaceous, earthy textured, relatively soft, white to buff or gray dolostone called "cotton rock", and a more massive, medium-grained, gray dolostone that weathers to a somewhat hackly surface texture and becomes dark on exposure. The formation contains chert, some minor beds of greenish shale, and occasional thin interbedded sandstone. ... To date, there has been no success in differentiating the Cotter Formation from the Jefferson City Formation in Arkansas, although the contact is considered disconformable. The thickness is about 340 feet in the vicinity of Cotter, but the interval may range up to 500 feet thick in places."

Altitudes of the top of the Cotter Dolomite in the study area are interpolated using the digital surface to be between $-655 \mathrm{ft}$ and 1,426 ft (fig. 14). Thickness of the Cotter Dolomite (fig. 15) is between 108 and 1,240 ft in the study area.

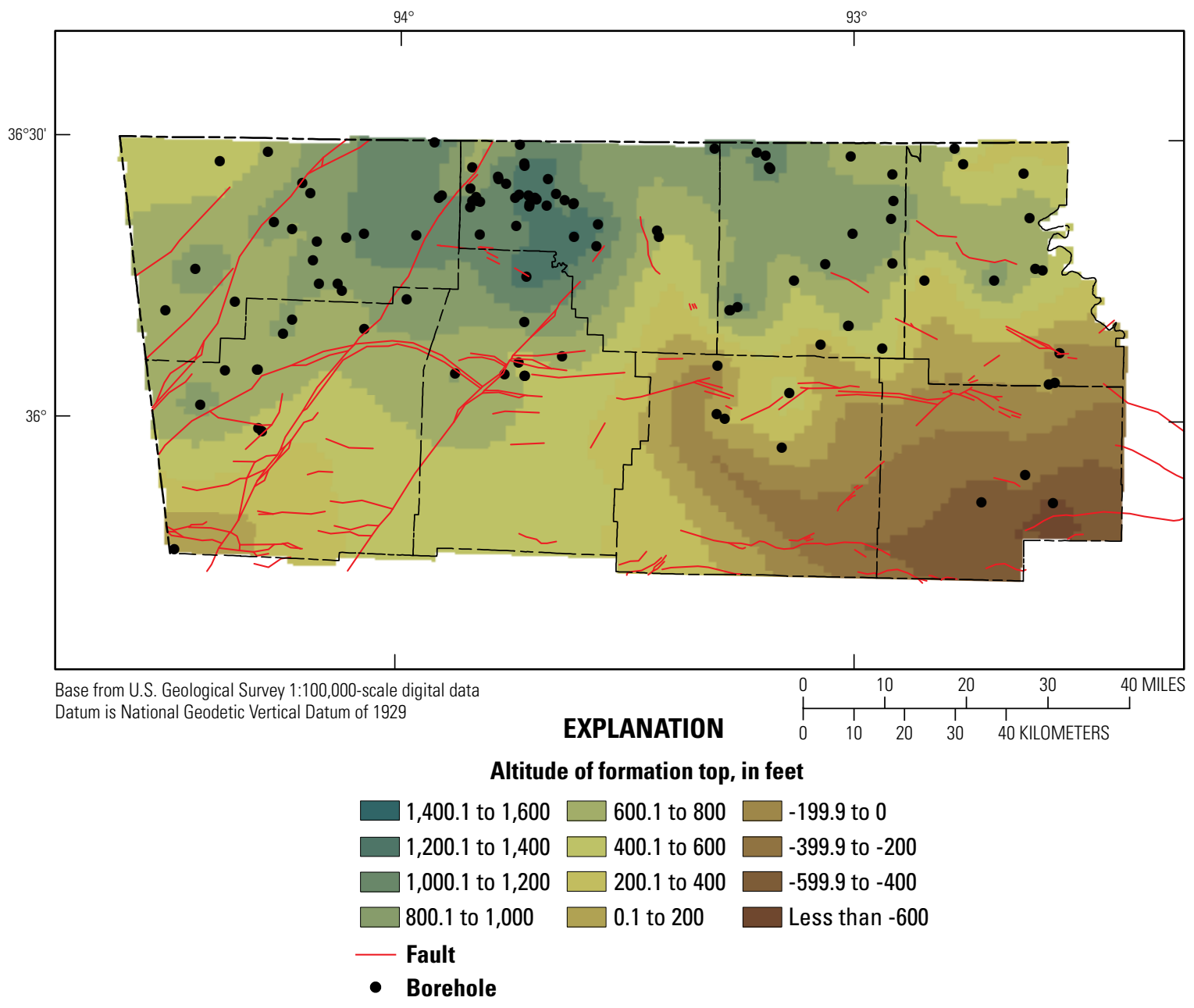

Figure 14. Altitude of the top of Cotter Dolomite. 


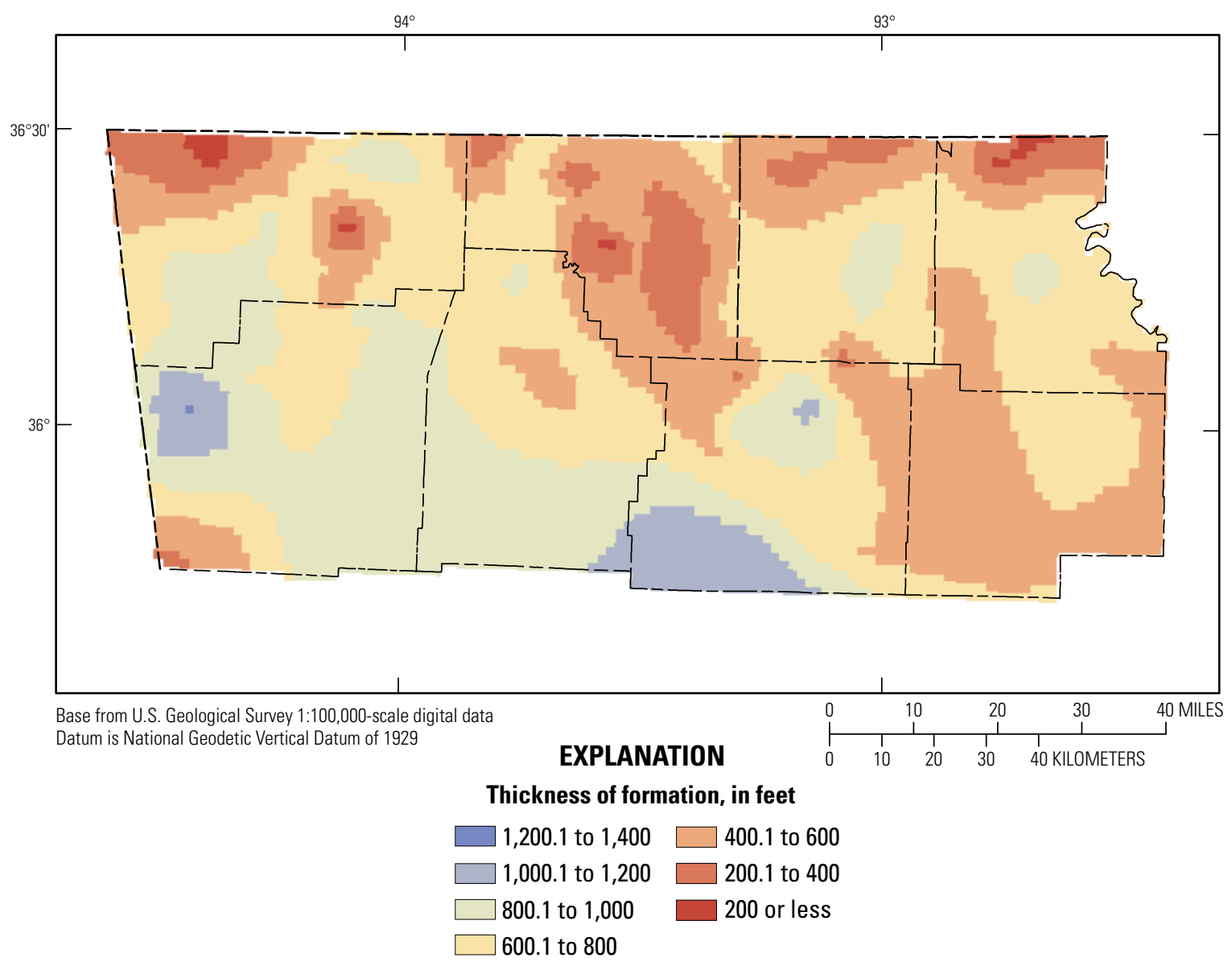

Figure 15. Thickness of Cotter Dolomite. 


\section{Roubidoux Formation}

The Roubidoux Formation of Early Ordovician age is characterized as a light-colored, finely granular to mediumcrystalline dolomite, dolomitic sandstone, and chert (Pugh, 2008). The Roubidoux Formation does not outcrop in Arkansas but is an important water-producing unit within the Ozark aquifer (Imes and Emmett, 1994). Prior and others
(1999) estimated the thickness of the Roubidoux Formation to be as much as about $360 \mathrm{ft}$ based on well data that allowed identification of the top and bottom of the formation.

Altitudes of the top of the Roubidoux Formation in the study area are interpolated using the digital surface to be between -1,189 ft and 1,221 ft (fig. 16). Thickness of the Roubidoux Formation (fig. 17) is between 0 and $670 \mathrm{ft}$ in the study area.

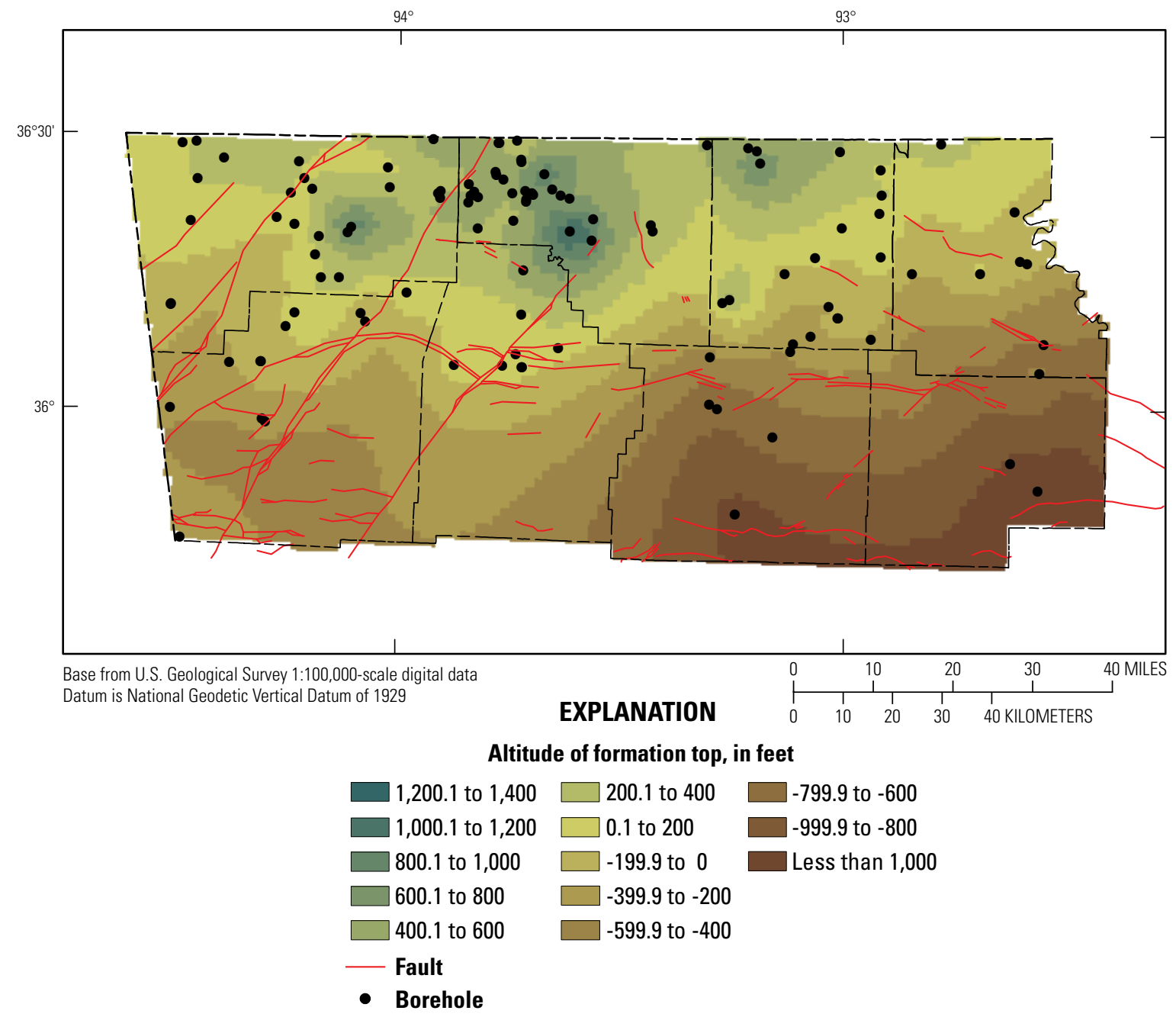

Figure 16. Altitude of the top of Roubidoux Formation. 


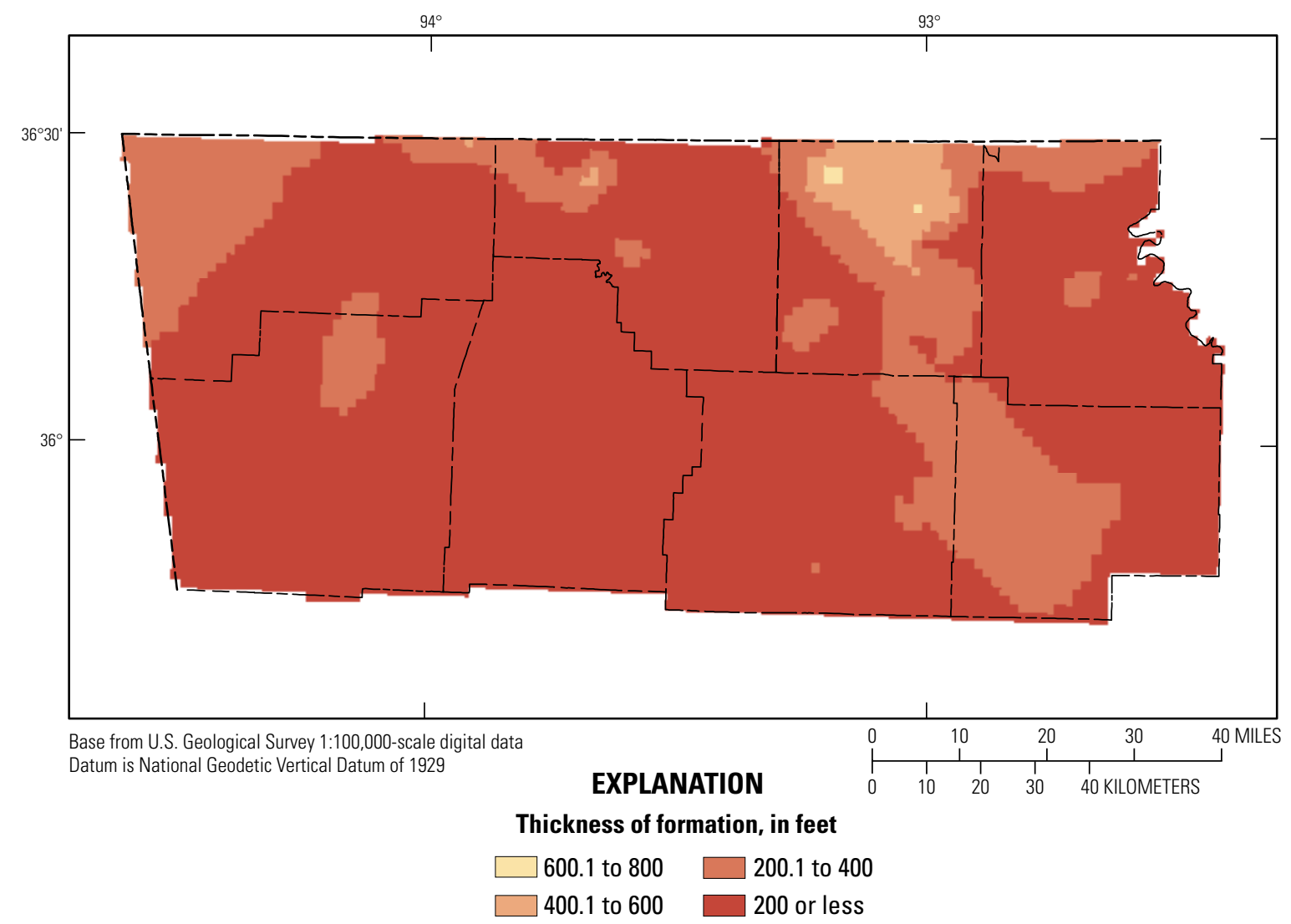

Figure 17. Thickness of Roubidoux Formation. 


\section{Gasconade Dolomite}

The Gasconade Dolomite of Early Ordovician age consists of a series of dolomite beds interstratified with thin beds of sandstone that underlie the Roubidoux sandstone (U.S. Geological Survey, 2012). The Gasconade Dolomite does not outcrop in Arkansas.
Altitudes of the top of the Gasconade Dolomite in the study area are interpolated using the digital surface to be between $-1,173 \mathrm{ft}$ and $1,001 \mathrm{ft}$ (fig. 18). Thickness of the Gasconade Dolomite (fig. 19) is between 10 and 1,123 ft in the study area.

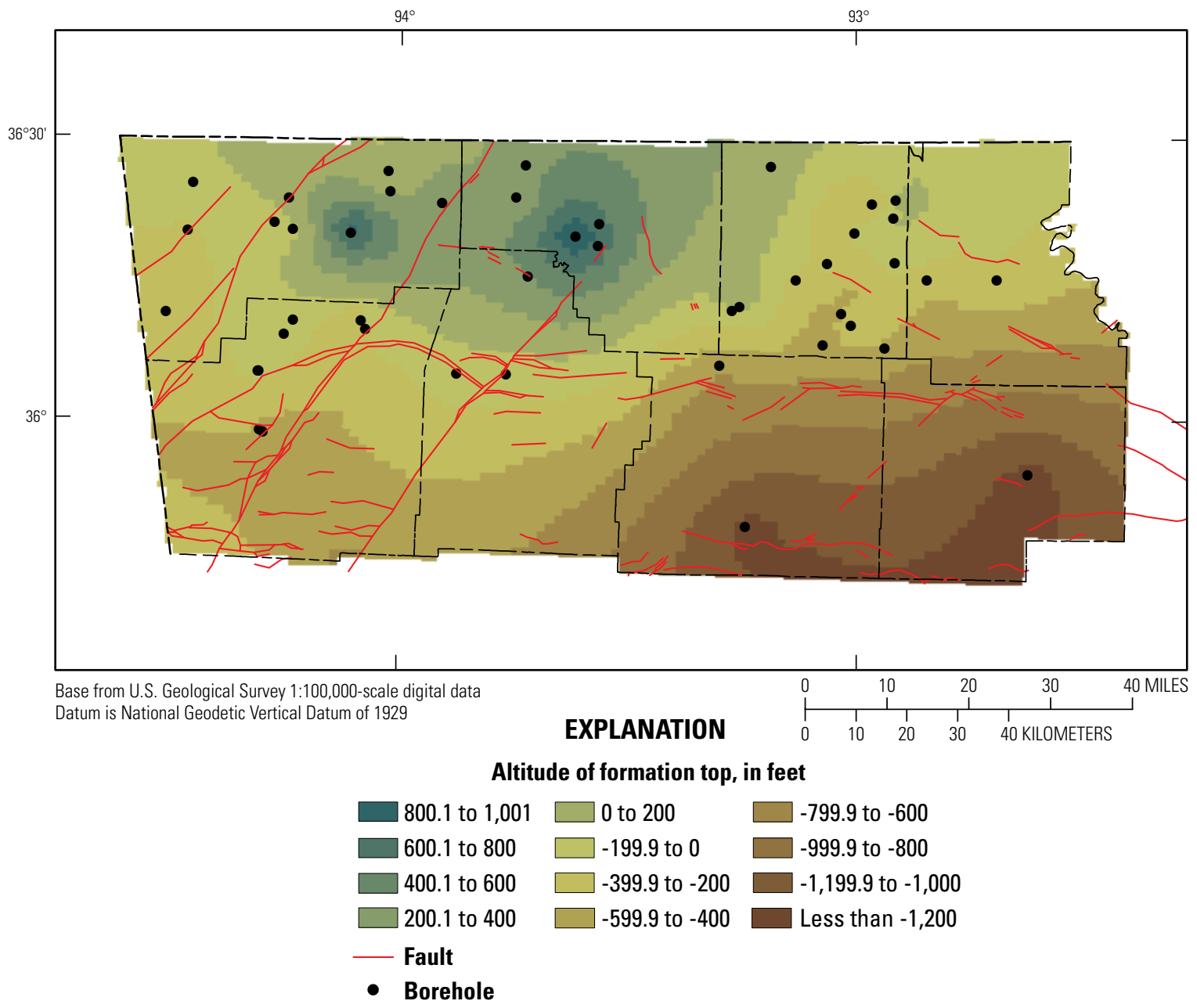

Figure 18. Altitude of the top of Gasconade Dolomite. 


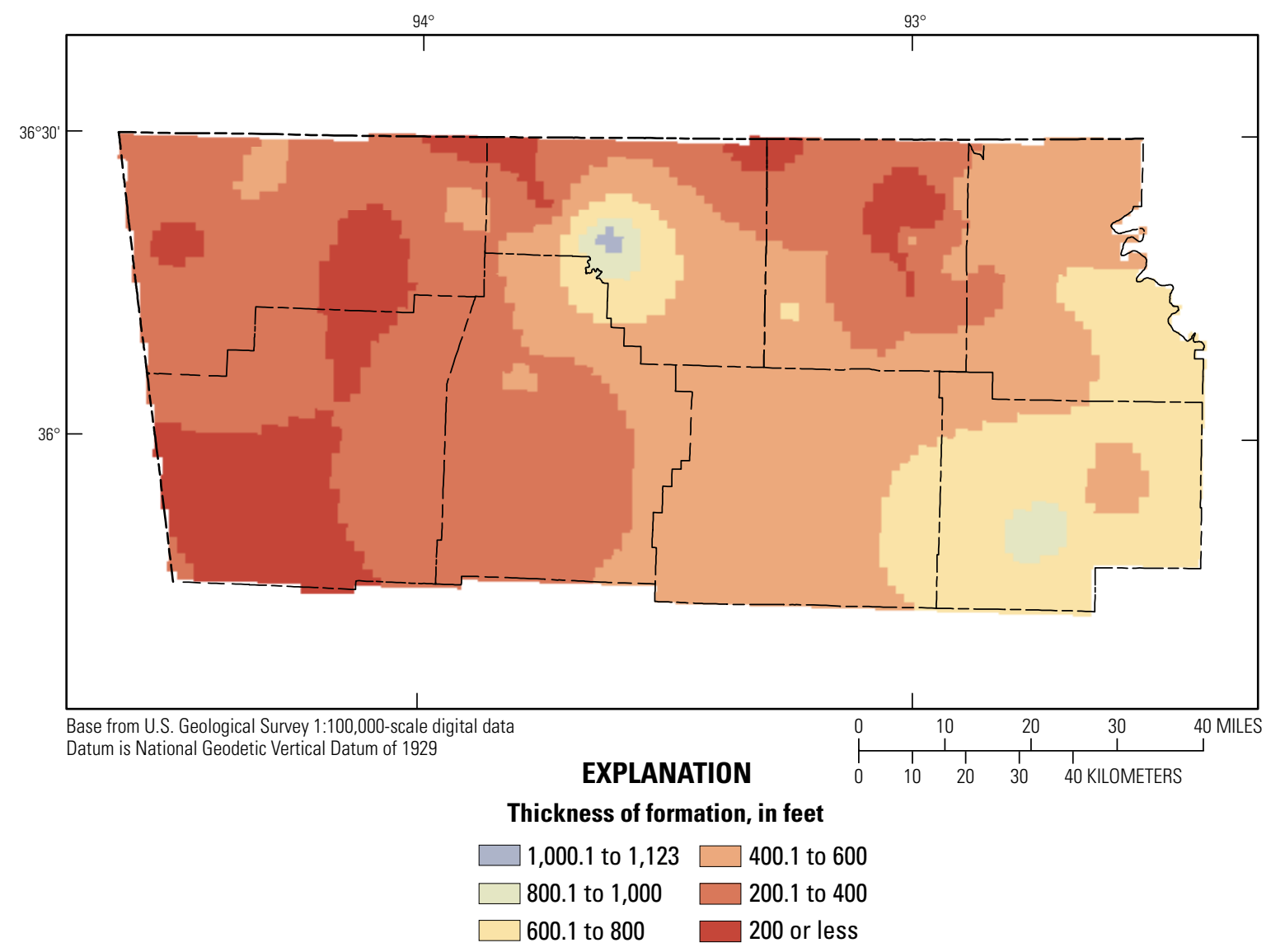

Figure 19. Thickness of Gasconade Dolomite. 


\section{Gunter Sandstone}

The Gunter Sandstone of Early Ordovician age is a white to gray quartz sandstone. Maximum thickness in Arkansas is approximately $100 \mathrm{ft}$ (Pugh, 2008). Altitudes of the top of the Gunter Sandstone in the study area are interpolated using the digital surface to be between $-2,111 \mathrm{ft}$ and $820 \mathrm{ft}$ (fig. 20). The Gunter Sandstone does not outcrop in Arkansas. Thickness of the Gunter Sandstone in the study area was not calculated as the top of the Gunter Sandstone was the lowest surface for which altitudes were interpolated.

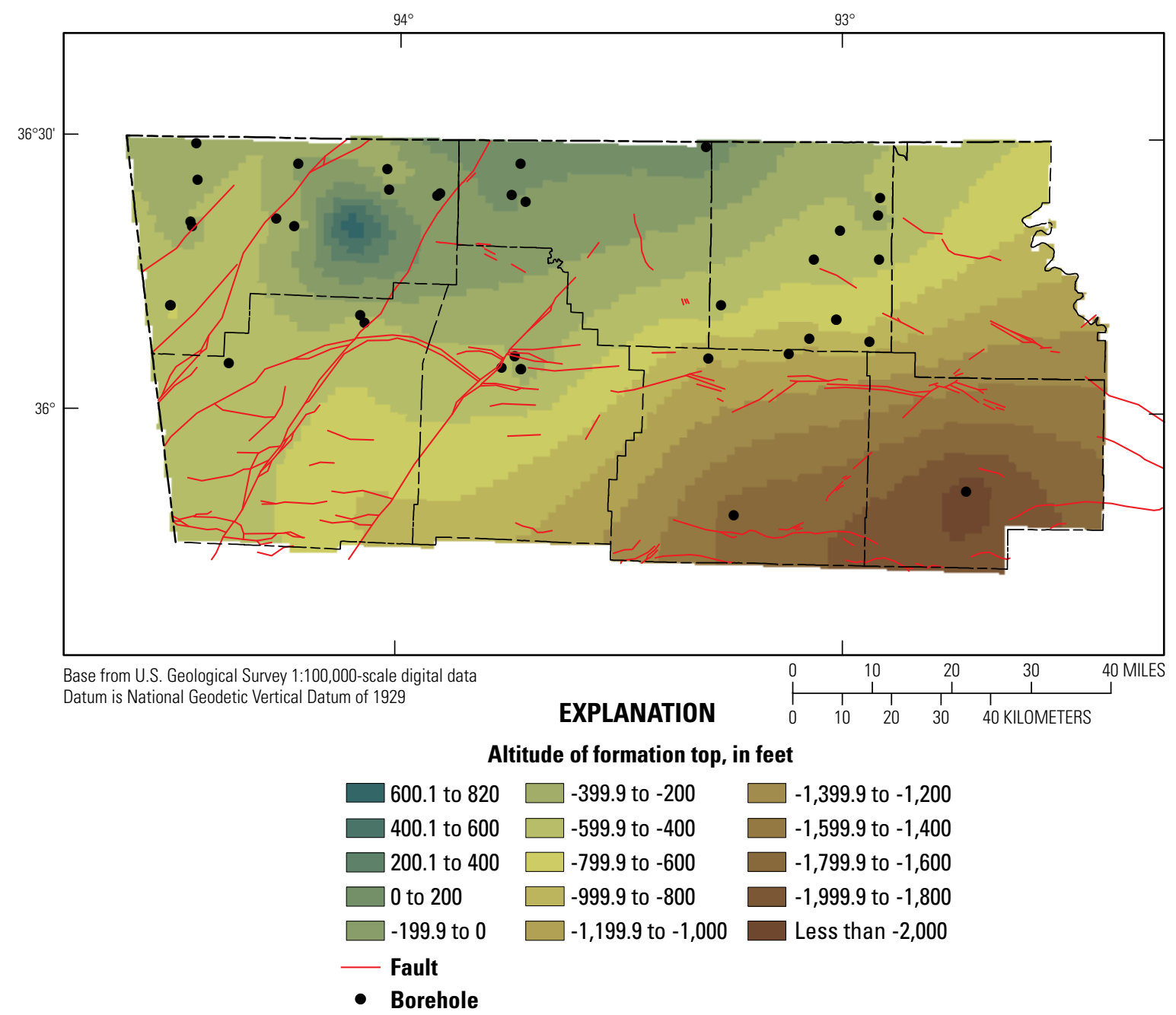

Figure 20. Altitude of the top of Gunter Sandstone. 


\section{Limitations of Analysis}

The representation of the hydrogeologic surfaces in this report are by necessity a simplification of reality. Simplification occurs in the assumptions that the hydrogeologic surfaces are continuous, that the surfaces can be adequately interpolated using sparse datasets, and that the algorithm used in the generation of the surfaces was adequate. Faults are acknowledged to occur in the study area, but for this version of the hydrogeologic-surfaces representation, displacement of the surfaces by these faults was not incorporated. Uncertainties along the edges of the study area exist, particularly along the Missouri border, because data outside the study area were not used in the interpolation process. The number and density of data points available for each surface were variable. Considerable judgement and interpretation went into the selection of the hydrogeologicsurface altitude values at each borehole geophysical log location. The decision to assign the top of a hydrogeologic formation at a particular altitude was subjective based on the interpretation of the available log data. The contouring algorithm used in the construction of the hydrogeologic surfaces is limited in representing abrupt spatial changes in altitude values. Differences in previously reported thicknesses and those reported in this report occur, in part, because of these limitations of analysis as well as differences in the availability of data for these analyses.

\section{Summary}

Digital surfaces of selected hydrogeologic units in northwestern Arkansas were created using geophysical logs, drillers' logs, geologist-interpreted formation tops, and previously published maps for an area that covers approximately 6,040 square miles containing Benton, Washington, Carroll, Madison, Boone, Newton, Marion and Searcy Counties. Determination of the top of each hydrogeologic unit of interest on a geophysical log was made based partly on previously published reports and maps and also from drillers' logs. Digital surfaces and thicknesses of nine hydrogeologic units were interpolated over the study area. Thicknesses of some units exceeded previously reported amounts by several hundred feet as a function of differences in available data for analysis and limitations of the analyses performed.

\section{References Cited}

Arkansas Geological Survey, 2012, Stratigraphy: Ozark Plateaus, accessed February 22, 2012, at http://www.geology.ar.gov/geology/strat_ozark_plateaus. htm.
Czarnecki, J.B., Gillip, J.A., Jones, P.M., and Yeatts, D.S., 2009, Groundwater-flow model of the Ozark Plateaus aquifer system, northwestern Arkansas, southeastern Kansas, southwestern Missouri, and northeastern Oklahoma: U.S. Geological Survey Scientific Investigations Report 2009-5148, 62 p.

Environmental Systems Research Institute, 2012, ArcGIS for desktop, accessed February 22, 2012, at http://www.esri. com/software/arcgis/arcgis-for-desktop/index.html.

Haley, B.R., Glick, E.E., Bush, W.V., Clardy B.F., Stone, C.G., Woodward, M.B., and Zachry, D.L., 1993, Geologic map of Arkansas: Arkansas Geological Survey, $1 \mathrm{pl}$.

Hart, R.M., and Clark, B.R., 2008, Geophysical log database for the Mississippi Embayment Regional Aquifer Study (MERAS): U.S. Geological Survey Scientific Investigations Report 2008-5192, $7 \mathrm{p}$.

Hart, R.M., Clark, B.R., and Bolyard, S.E., 2008, Digital hydrogeologic surface and thickness of the Mississippi Embayment Regional Aquifer Study (MERAS) area: U.S. Geological Survey Scientific Investigations Report 20085098, 33 p.

Holland, T.W., 2007, Water use in Arkansas, 2005: U.S. Geological Survey Scientific Investigations Report 20075241, $32 \mathrm{p}$.

Hutchinson, M.F., 1989, A new method for gridding elevation and stream line data with automatic removal of spurious pits: Journal of Hydrology, v. 106, p. 211-232.

Imes, J.L., 1990, Major geohydrogeologic units in and adjacent to the Ozark Plateaus Province, Missouri, Arkansas, Kansas, and Oklahoma-Ozark aquifer: U.S. Geological Survey Hydrogeologic Investigations Atlas HA-711-E, 3 sheets, scale 1:750,000.

Imes, J.L., and L.F. Emmett, 1994, Geohydrology of the Ozark Plateaus aquifer system in parts of Missouri, Arkansas, Oklahoma, and Kansas: U.S. Geological Survey Professional Paper 1414-D, 127 p.

Jorgensen, D.G., 1996, Analysis of regional aquifers in the central Midwest of the United States in Kansas, Nebraska, and parts of Arkansas, Colorado, Missouri, New Mexico, Oklahoma, South Dakota, Texas, and Wyoming-Summary: U.S. Geological Survey Professional Paper 1414-A, 67 p.

Kresse, T.M., Warner, N.R., Hays, P.D., Down, Adrian, Vengosh, Avner, and Jackson, R.B., 2012, Shallow groundwater quality and geochemistry in the Fayetteville Shale gas-production area, north-central Arkansas, 2011: U.S. Geological Survey Scientific Investigations Report 2012-5273, $31 \mathrm{p}$.

McFarland, J.G., 2004, Stratigraphic summary of Arkansas: Arkansas Geological Commission Information Circular 36, $38 \mathrm{p}$. 
Prior, W.L., Howard, J.M., McFarland, J.D, and Hill, S.S., 1999, Roubidoux Formation and Gunter Sandstone Member of the Gasconade Formation, major aquifers in northern Arkansas: Arkansas Geological Survey Water Resources Circular 17, 45 p.

Pugh, A. L., 2008, Potentiometric surface of the Ozark aquifer in northern Arkansas, 2007: U.S. Geological Survey

Scientific Investigations Report 2008-5137, 16 p.
Sheldon, M.G., 1954, Sample descriptions and correlations for selected wells in northern Arkansas: Arkansas Geological Survey Information Circular 17, 229 p.

U.S. Geological Survey, 2012, National Geologic Map Database, GEOLEX database, accessed January 13, 2012, at http://ngmdb.usgs.gov/Geolex/geolex_qs.html. 


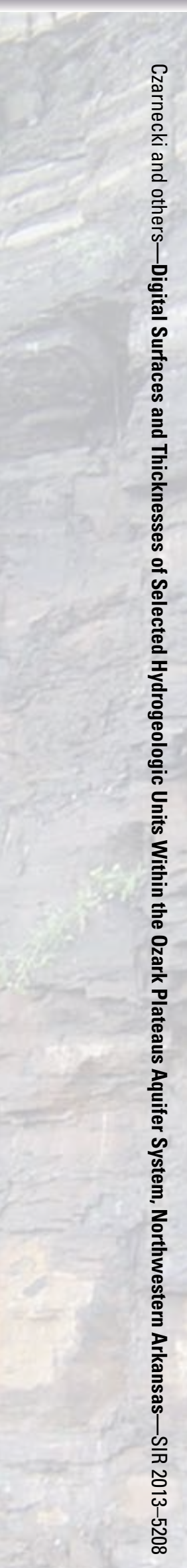

